\title{
Pandemi Sürecinde Kentsel Mekânı ve Gündelik Yaşam Pratiklerini Ritimanaliz ile Okumak: İstiklal Caddesi Örneği
}

\author{
Burcu Soygüzeloğlu ${ }^{1}$ \\ ORCID: 0000-0001-7113-5189
}

*

\author{
Eren Kürkçüoğlu² \\ ORCID: 0000-0002-3723-9803
}

\section{Öz}

Gündelik yaşamın çeşitli dinamikleriyle oluşan toplumsal etkinlikler, kentsel mekânın çok boyutlu yapısını oluşturmaktadır. Kentsel mekânlar, tarihsel süreçte yer alan önemli olaylar ile daha da karmaşık bir yapıya bürünmektedir. Bu anlamda sınır tanımaksızın geniş coğrafyalara yayılan salgın hastaliklar/pandemiler, kentsel mekânların yeniden biçimlenmesine sebep olan önemli bir etkendir. Günümüzde, COVID-19 sürecinde değişen ve dönüşen kentsel mekânlarda ilerleyen gündelik yaşam pratiklerini inceleyebilmek için kapsaml yöntemlere ihtiyaç duyulmaktadır. Bu noktada gündelik yaşam pratiklerini tek bir andan ziyade, süreç içinde inceleyen "ritimanaliz" önemli bir kavram olmaktadır. Çalışmanın ana çerçevesini oluşturan bu kavram, Lefebvre'in 2004 yılında yayımlanan "Ritimanaliz: Mekân, Zaman ve Gündelik Yaşam" kitabı üzerinden ele alınmaktadır. Çalışmada; gündelik yaşamda kentsel ritimlerin nasıl oluştŭ̆u ve nelerden etkilenebildiğgi, ritimanaliz kavramının kapsamı ve kentsel mekânda nasıl uygulandığ incelenerek içinde bulunduğumuz COVID-19 pandemisinin kentsel mekân ve gündelik yaşam pratiklerini nasıl etkilediğinin ritimler üzerinden okunması amaçlanmaktadır. Çalışma kapsamında; incelenen ritimanaliz yöntemi, pandemi süresince çeşitli fiziksel sınırlandırmaların uygulanarak etkileşimin kısıtlanması bakımından önemli bir örneklem olduğu düşünülen İstiklal Caddesi üzerinde gözlem, video kayıt ve davranışsal haritalama araçları kullanılarak uygulanmaktadır. Çalışmanın COVID-19 pandemisi sürecinde İstiklal Caddesi'ndeki dönüşümü ve değişen gündelik yaşam pratiklerini göstermesi açısından pandemi sonrasında yapılacak olan kentsel araştırmalara girdi oluşturacă̆ına ve kentsel tasarım sürecine katkı sağlayacă̆ına inanilmaktadır.

Anahtar Kelimeler: Covid-19 pandemisi, gündelik yaşam, İstiklal Caddesi, kentsel mekân, ritimanaliz

\footnotetext{
${ }^{1}$ Araş. Gör., Gebze Teknik Üniversitesi, E-mail: bsoyguzeloglu@gtu.edu.tr

${ }^{2}$ Dr. Öğr. Üyesi, İstanbul Teknik Üniversitesi, E-mail: ekurkcuoglu@itu.edu.tr

idealkent (c) Kent Araştırmaları Dergisi (Journal of Urban Studies)

http://idealkentdergisi.com

Geliş Tarihi Received Date: 14.02.2021 Kabul Tarihi Accepted Date: 27.08.2021
} 


\title{
Reading Urban Space and Practices of Everyday Life through Rhythmanalysis during the Pandemic: The Case of Istiklal Street
}

\author{
Burcu Soygüzeloğlu1 1 \\ ORCID: 0000-0001-7113-5189
}

*

\author{
Eren Kürkçüoğlu² \\ ORCID: 0000-0002-3723-9803
}

\begin{abstract}
Multi-dimensional urban spaces have reshaped with important events in the historical process. In this process, pandemics knowing no boundaries have been important factors changing the urban space. Nowadays, comprehensive methods are needed to examine the practices of daily life in changing urban spaces during the COVID-19 process. At this point, "rhythmanalysis" is an important method examining the practices of daily life in the process rather than a single moment. This method, forming the main framework of the study, is addressed through Lefebvre's book "Rythmanalysis: Space, Time and Everyday Life" published in 2004. This study aims to examine how urban rhythms are formed in daily life and what they can be affected by, and how the COVID-19 pandemic affects urban spaces and daily life practices through rhythms. Within the study, rhythmanalysis method is implemented in Istiklal Street, considered to be an important sample in terms of its changing structure due to physical restrictions imposed during the pandemic, by using observation, video recording, and behavioral mapping tools. It is believed that the study will provide input for urban studies to be carried out in the post-COVID-19 process by revealing the transformation of daily life practices in Istiklal Street.
\end{abstract}

Keywords: Covid-19 pandemic, everyday life, Istiklal Street, rhythmanalysis, urban space

\footnotetext{
${ }^{1}$ Res. Assist., Gebze Technical University, E-mail: bsoyguzeloglu@gtu.edu.tr

${ }^{2}$ Assist. Prof. Dr., Istanbul Technical University, E-mail: ekurkcuoglu@itu.edu.tr

idealkent @ C Kent Araştırmaları Dergisi (Journal of Urban Studies) 


\section{Giriş}

Kentlerin ve kentsel mekânların farklı değişim ve dönüşüm şekilleri incelenirken geçmişe, günümüze ve geleceğe yönelik süreçleri ve gelişmeleri ortaya koyarak tartışma ortamı oluşturmak gerekmektedir. Kentsel mekânlar, çok boyutlu yapıları çerçevesinde bir bütün olarak düşünülmelidir. Erdönmez ve Akı'ya (2005) göre kentleri bütün olarak ele almayı gerektiren, kentlilerin farklı hayatları, birbirleri ve mekânlarla olan ilişkileri ile bu sosyal yapının kentsel mekânda kendini göstermesidir. Kentsel mekânlar, içerisinde yaşayan bireyleri ve toplumu biçimlendirirken benzer şekilde bireyler ve birbirleriyle olan ilişkilerinden etkilenerek her geçen gün yeniden şekillenmektedir. Bu sürekli devinim ve değişim hali, kentleri canlı ve dinamik tutarak ritmik bir yapı oluşturmaktadır. Bu hal; kentsel mekânların tarihsel süreç içerisinde yer alan sanayi devrimi, küreselleşme, iletişim ve bilişim teknolojilerindeki gelişmeler gibi çeşitli önemli olaylar ile daha da karmaşık bir yapıya sahip olmasiyla devam etmektedir. Bahsedilen olayların yanı sıra, kentsel mekânların yeniden biçimlenmesine sebep olan bir diğer etken ise sınır tanımadan geniş coğrafya ve alanlara yayılan, bireyleri, toplumları, onların kentle olan ilişkilerini, rutin ve alışkanlıklarını etkileyen salgın hastalıklar/pandemiler olmaktadır.

Günümüzde; Çin Halk Cumhuriyeti'nin Wuhan kentinde 2019 yllının aralık ayında başladığı öngörülen, birkaç ay gibi kısa bir sürede diğer ülke ve kentlere yayılmasiyla 11 Mart 2020 tarihinde "pandemi" olarak nitelendirilen COVID-19 salgını (Aslan, 2020, s. 38-39) ve bu salgını durdurmaya yönelik alınan tedbirler, kamusal alan kullanımını sinırlandırarak bu alanlara olan ihtiyacı arttırmaktadır. İçerisinde olduğumuz pandemiyle birlikte sosyal bir kent yaşamının olmazsa olmazlarından olan kamusal alanların kullanımı, ancak sosyal mesafe kurallarına uygunluğuna ve toplum sağlığ için herhangi bir risk barındırmamasına bağlıdır (Çiçek, 2021, s. 315). O'Connor'un (2020) pandemi sürecindeki kamusal alan kullanımı üzerine yaptığı çalışmaya göre kullanıcıların kamusal alanlar yerine, kapı önlerini, kaldırımları ve sokakları günlük aktiviteleri arttırıcı nitelikte, çoğunlukla temel ihtiyaçları karşılamak amacıyla kullanmaya başladığı görülmektedir. Benzer şekilde James (2020), pandemi sürecindeki buluşma eylemlerinin fiziksel ortamdan sanal ortama taşındığına, şehir merkezlerindeki aktivite yoğunluğunun azalarak zorunlu aktiviteler üzerinden ilerlediğine ve buna bağlı olarak gruplar arası karşılıklı etkileşimin azaldı- 
ğına dikkat çekmektedir. Pandemiyle birlikte gündelik yaşamın dönüşüme uğradığını vurgulayan Kasinitz (2020) ise bu dönüşümü farklı ölçeklerde yeniden tanımlanan kullanıcı-mekân ilişkileri üzerinden açıklamaktadır.

Sürecin hali hazırda devam ediyor olmasından ötürü pandeminin olası etki ve sonuçlarına kesin olarak ulaşmak zor olsa da pandemi, etkileyerek dönüşüme uğrattığı kentsel mekân ve gündelik yaşam pratiklerini yeniden düşünülmesi gereken bir tartısma konusu haline getirmektedir ve bu konuda kapsamlı yöntemlere ihtiyaç duyulmaktadır. Bu anlamda Wunderlich'e (2016) göre doğal olaylar (force of nature) ve yapay alanlarla sınırlanan sosyal ve insan aktivitelerinin üst üste binmesiyle kentsel mekânlar, çok çeşitli kentsel ritimleri incelemek için önemli bir bağlam olarak karşımıza çıkmaktadır. Burada sözü edilen doğal olaylar kapsamında günümüzdeki COVID-19 pandemisini alan bu çalışma, kentsel mekân ve gündelik yaşamın ritimler ve mekândaki kullanıcı hareketleri üzerinden nasıl tanımlanabileceğini inceleyerek pandemi sürecinde değişen kentsel mekânı ve gündelik yaşam pratiklerini kentsel ritimler aracılığıyla okumayı amaçlamaktadır.

\section{Kentsel Mekân-Gündelik Yaşam İlişkisi: Kentsel Ritimler}

Ritim, kasaba ve şehirlerimizin işleyişinde, kentsel yaşamda ve uzaydaki harekette bulunur. Doğal, biyolojik ve sosyal zaman çizelgemizin, bedenlerimizin ve toplumumuzun ritimlerinin çarpışmasında, ritimlerin analizi, günlük yaşam sorununa ayrıcalıklı bir bakış açısı sağlar (Elden, 2004, s.8).

Ritim kavramının etimolojik kökeni, milattan önce 7. yüzyılda Yunan trajedi ve felsefesindeki "skhema" veya "form" kavramlarıyla eş anlamlı olan "rhythmos" kelimesine dayanmaktadır. Burada "skhema"; sabit bir form olarak tanımlanırken "rhythmos"; hareket halindeki, akışkan, değişken form anlamına gelmektedir (Marcus, 2014, s. 9). Antik Yunan filozoflarından beri tartışlan ritim; günümüzde dilbilim, güzel sanatlar, biyoloji, fizik, psikoloji gibi birden fazla disiplinde kullanılarak birbirinden farklı tanımlara sahip olabilmektedir. TDK'ya (2021) göre ritim, “Bir kompozisyonda farklı öğelerin sıra ile ve belli aralıklarla birbirlerini izlemesi" ve "Bir dizede, bir notada vurgu, uzunluk veya ses özelliklerinin, durakların düzenli bir biçimde tekrarlanmasından doğan ses uyumu, dizem" olarak tanımlanmaktadır. Sosyomekânsal perspektiften ise düzenli aralıklarla yinelenen, güçlü ve zayıf unsurların art arda geldiği hareket veya tekrar eden olay dizileri olarak tanımlanabilen ritim; sosyal ve fiziksel mekânda ritimlerin nasıl anlaşılabileceği ile 
ilgili ipucu vermektedir. Bu noktada Lefebvre (2004), kendinden önceki filozof ve araştırmacılardan farklı olarak ritim kavramının yalnızca tanımı ve önemi değil, aynı zamanda nasıl analiz edilebileceği üzerine de çalışmalar yaparak bu kavrama farklı bir boyut getirmektedir. "Bir yer, bir zaman ve bir enerji tüketimi arasında etkileşim olan her yerde ritim vardır" (Lefebvre, 2004, s. 15). Ritimleri gündelik yaşam bağlamında ilk kez inceleyen Lefebvre, zamana bir şekilde bağlı olan her durumun düzenli birlikteliklere ve tekrarlara sahip olduğundan, bu durumun ise ritmi var ettiğinden bahsetmektedir. $\mathrm{Bu}$ anlamda yineleme/devinim (repetition), ölçü (measure) ve hareket (movement) olmak üzere ritimlerin üç temel özelliğini ortaya koymaktadır. Ritimlerin oluşmasında etkili olan ögelerin ve oluşan ritimlerden kaynaklı ortaya çıkan niteliksel durumların tartısılması gerekliliğini ve belirli bir metriğe göre az ya da çok yoğun aktivite süreleriyle tekrar tekrar vurgulanan bir hareketteki yinelemenin gündelik yaşamdaki kentsel mekânda ritimlerin nasıl izlenip algılanacağına dair çerçeve sunduğunu vurgulamaktadır. Bu nedenle Lefebvre, ortaya koymuş olduğu "ritimanaliz" kavramı için ana prensipler oluşturmuştur. Ona göre ritim, güçlü ve zayıf zamanlar gibi tam anlamıyla işaretlenmiş karşıt olan zamansal öğeler ve tüm bu unsurları beraberinde getiren genel bir hareketi gerektirmektedir (Lefebvre ve Régulier, 2004, s. 78).

Gündelik yaşamdaki ritimlerin ve hangi biçimlerde algılandıklarının irdelendiği "Ritimanaliz: Mekân, Zaman ve Gündelik Yaşam" kitabında ritimlerin diğer ritimlerle ilişkili olarak algılanabileceğini söyleyen Lefebvre (2004); yalnızca tekli ritimleri değil, ayn zamanda etkileşim biçimlerini de anlamaya çalışmaktadır. Ritimlerin kendi arasındaki etkileşim biçimleri doğrultusunda sırasıyla; birden fazla ritmin uyumlu bir şekilde bir arada bulunmasındaki etkileşim (öritmi/eurhythmia), birden fazla ritmin uyumsuz bir şekilde bir arada bulunması (aritmi/arrhythmia) ve farklı ritimlerin uyumsuzluk olmaksızın bir arada bulunması (poliritmi/polyrhythmia) tanım ve kavramlarını ortaya koymaktadır (Lefebvre, 2004, s. 16). Bu kavramlardan yola çıkarak hızlı ulaşım, iletişim ve bilişim alanlarındaki gelişmelerle büyüyen kentler; artan hareketlilik ve farklı ritimlerin bir aradalığı sayesinde poliritminin gözlenebildiği örneklem alanlar olarak değerlendirilebilmektedir. Bu süreç içindeki değişimler; zaman-mekân, mekân-birey ve birey-toplum ilişkilerini muğlaklaştırmakta ve bu durum farklı yaklaşımlar ile yapılacak araştırma ve düzenlemelere olan ihtiyacı getirmektedir. Başta günümüzdeki COVID-19 pandemisinin kentsel mekân ve gündelik yaşam pratikleri üzerinde olumsuz yönde gerçekleşen değiştirici ve dönüştürücü etkisiyle ilişkilendirilebilecek aritmi 
kavramı olmak üzere bahsedilen diğer kavramlar da kentsel ritimlerin incelenme gereksinimini ortaya koymaktadır.

Kentsel bağlama özgü olan, ritimler için çerçeve ve bağlam sunan kentsel ritimler; yoğun ve birbiriyle ilişkili sosyal ve insan aktivitelerinden oluşmaktadır (Wunderlich, 2016, s. 7). Kentsel ritimler, gündelik yaşam ritimleri ve mekânsal ritimlerin arasındaki ilişkiden ortaya çıkmaktadır. İnsan aktivitelerin olduğu her yerde oluşarak insan hareketlerinin koşulunu oluşturan gündelik yaşam ritimlerinin bir arada olma durumu ve kendi içindeki ilişkisi, kentsel mekânda var olmaktadır. Böylelikle gece-gündüz, saat ve mevsim farkları gibi çeşitli döngüsel olaylardan etkilenen mekânsal ritimler ise insan ve mekân arasındaki bu ilişkiden doğmaktadır. Bu noktada Lefebvre (2004), döngüsel ve doğrusal ritimler olarak nitelendirilen, gündelik yaşamdaki iki farklı ritim türünden bahsederek bunların bir araya gelişindeki (poliritmi) uyum veya uyumsuzlukla öritmi veya aritminin ortaya çıtığını vurgulamaktadır. Döngüsel ritimler (cyclical rhythms); süreçler veya hareketler, dalgalanmalar, titreşimler, dönüşler olarak tanımlanabilmekte ve gündüz-gece, mevsimler, yıllar, saatler ve aylar gibi kısa aralıklı, dönüşümlü yinelemelerden oluşmaktadır (Lefebvre ve Régulier, 2004, s. 76). Doğrusal ritimler (linear rhythms) ise eylemler ve hareketler dizilerinden (Lefebvre, 2004, s. 18) veya uzun/kısa dönemlerle ayrılmış özdeş gerçeklikler dizisinden (Lefebvre ve Régulier, 2004, s. 76) oluşmaktadır. Sosyal pratiklerden ve genel olarak insan aktivitelerinden kaynaklanan dayatılmış, monoton yapılardır. (Wunderlich, 2016, s. 9) Bu anlamda Lefebvre'in (2004) ritimanaliz yöntemi, kentsel ritimlerin kaynağı olan gündelik hayatta var olan döngüsel ve lineer ritimler arasında oluşan ilişkiyi incelemektedir.

Kentsel ritimleri çeşitli yöntemlerle incelemek; kentsel mekândaki olayların ve insan aktivitelerinin nasıl ilerlediğini ve kentsel mekânın zamansal özelliklerini anlamaya olanak sağlarken kentsel mekân ve gündelik yaşamda çeşitli sebeplerle yaşanan değişim ve dönüşümleri, buna bağlı olarak ortaya çıkan sorunları ortaya koymaktadır. Bu yönüyle bu çalışmada kentsel ritimler; COVID-19 pandemisinin kentsel mekân ve gündelik yaşam üzerindeki değiştirici ve dönüştürücü etkisini analiz etmede kullanılabilecek bir araç olarak değerlendirilmektedir.

\section{Yöntem}

Lefebvre' in (2004) ritimanaliz yöntemi; gündelik yaşam ritimleri ve mekânsal ritimlerden oluşan kentsel ritimleri analiz ederken birey, günlük ritimler, alışkanlık ve rutinler, zamansal değişimler, anlık olaylar, yapılı çevre ve kentsel 
fonksiyonlar, kentsel mekândaki değişen nitelik, kullanım ve hareket biçimleri gibi çeşitli konulara ipuçları da veren, gündelik yaşam pratiklerini süreç içerisinde inceleyen önemli bir yaklaşımdır. Bununla birlikte incelenen çalışmalar (Cihanger Ribeiro, 2019; Gümüş ve Yılmaz, 2020; Marcu, 2017; Simpson, 2012; Zecca, Gaglione, Laing ve Gargiulo, 2020), bu yöntemin tek başına yeterli olmadığ için kural olarak genelleştirilmesindense araştırmacılar tarafindan farklı yöntemlerle yorumlanarak kullanılması gerektiğini savunmaktadır. İncelenen çalışmalar içinde Zecca, Gaglione, Laing ve Gargiulo (2020), kullanıcı akış yoğunluklarının oluşturduğu ritimleri nitel ve nicel analizler üzerinden coğrafi bilgi sistemleri ortamında inceleyerek; Gümüş ve Yılmaz (2020) ise mekân dizimi ile algısal ve davranışsal haritalama yöntemlerini ritimanaliz yaklaşımıyla bütünleştirme yoluyla sistematik okuma modeli oluşturarak öne çımaktadır.

Bu çalışmanın da ana yöntemini oluşturan ritimanaliz, Lefebvre' in 2004 yılında yayımlanan "Ritimanaliz: Mekân, Zaman ve Gündelik Yaşam" kitabı üzerinden ele alınmaktadır. Çalışmada kentsel mekân ve gündelik yaşamda kentsel ritimlerin nasıl oluştuğu ve nelerden etkilenebildiği, ritimanaliz kavramı ve kentsel mekânda nasıl uygulandığı açıklanmış olup içinde bulunduğumuz COVID-19 pandemisinin kentsel mekânı ve gündelik yaşamı nasıl etkilediğinin örneklem alan olan İstiklal Caddesi üzerinde incelenmesi amaçlanmaktadır. Oluşturulan teorik çerçeve ve temel alınmış olan ritimanaliz yöntemi; gözlem, video kayıt ve davranışsal haritalama yöntemleriyle desteklenerek alanda uygulanmaktadır. Bu bağlamda alan ve alandaki gündelik yaşam pratikleri; pandemi dolayısıyla değişen ve yeni oluşan ritimler üzerinden sırasıyla aktivitelere göre kullanıc yoğunluğunun oluşturduğu ritimler, cadde boyunca kullanıcı çeşitliliğinin ve aktivitelerin oluşturduğu ritimler olmak üzere üç başlık çerçevesinde incelenmektedir. Bu başlıklar incelenirken Lefebvre'in belirtmiş olduğu ve bir önceki bölümde değinilen döngüsellik, öğlen ve akşam olmak üzere iki farklı zaman dilimi üzerinden ele alınmaktadır. Bu noktada gün içerisinde yapılan genel gözlemlerde en yüksek yaya yoğunluğu ve buna bağlı ritim akışının gözlemlendiği saat aralıkları seçilmiştir. Aktivitelere göre kullanıc yoğunluğunun oluşturduğu ritimler incelenirken Lefebvre'in kentlerin hem içini hem dışını gözlemlemeyi ve çoklu ritimleri incelemeyi sağlayan önemli bir nokta olarak nitelendirdiği çeşitli gözlem noktaları İstiklal Caddesi üzerinde kurgulanmaktadır. İstiklal Caddesi'nin gerek pandemi öncesi gerekse sürecindeki karakter ve kullanımları, çevre bağlantıları, sahip olduğu hareketlilik ve ritimler düşünüldügünnde Taksim Meydanı girişi, Galatasaray 
Meydanı ve Şişhane Metro istasyonu önü olmak üzere üç belirgin nokta karşımıza çıkmaktadır (Şekil 1). 1. gözlem noktasının İstiklal Caddesi'nin ana girişlerinden biri olarak Taksim Meydanı, Gezi Parkı ve Cihangir, Tarlabaşı gibi konut alanlarına yakınlığıyla; 2. gözlem noktasının cadde üzerindeki mekânsal kullanımların farklılaşma gösterdiği nokta olarak kuzeyde Tarlabaşı, güneyde ise Tomtom Mahallesi'ne uzanan ulaşım bağlantılarına sahip olmasıyla; 3 . gözlem noktasının ise caddenin bir diğer girişi olarak Tünel Meydanı'na yakınlı̆ı̆ ile öne çıktığı düşünülmektedir. Bu üç gözlem noktasından üçer farklı günde, öğlen saat 13.00-13.15 ve akşam 20.00-20.15 saatlerinde video kayıtları alınarak çift yönlü sayımlar yapılmakta ve aktivitelere göre kullanıcı yoğunluğunun oluşturduğu ritimler ölçülmektedir. Ritimleri akış içerisinde gözlemlemenin farklı çıktılar verebileceği düşünüldügüünden cadde boyunca kullanıcı çeşitliliğinin ve aktivitelerin oluşturduğu ritimler, cadde üzerinde pandemi ve buna bağlı alınan tedbirler kapsamında değişen ritim akışları üzerinden ayrı ayrı değerlendirilmektedir. Bu kapsamda İstiklal Caddesi'nin Taksim ve Tünel Meydanı girişi arasında, öğlen saat 12.30-12.47 ve akşam 19.30-19.47 saatlerinde 17'şer dakika süren iki farklı yürüyüs gerçekleştirilerek kullanıcıların gerçekleştirdiği aktiviteler davranışsal haritalama ile analiz edilmekte ve caddedeki binaların zemin kat kullanımlarıyla birlikte düşünülerek yorumlanmaktadır. Bu yöntem ve araçlar yoluyla elde edilen, İstiklal Caddesi'nin COVID-19 sürecindeki durumuna dair detaylı bilgi veren bulgular; COVID-19 öncesindeki duruma dair edinilen izlenimler, literatürde bulunan çalışmalar ve COVID-19 sonrası için yapılabilecek öngörüler/öneriler çerçevesinde yorumlanarak değerlendirilmektedir. Bu şekilde COVID-19 sürecinin kentsel mekân ve gündelik yaşam pratikleri üzerindeki etkilerinin anlaşılması ve COVID-19 süreci sonrası için bir tartısma ortamı yaratılması amaçlanmaktadır. 


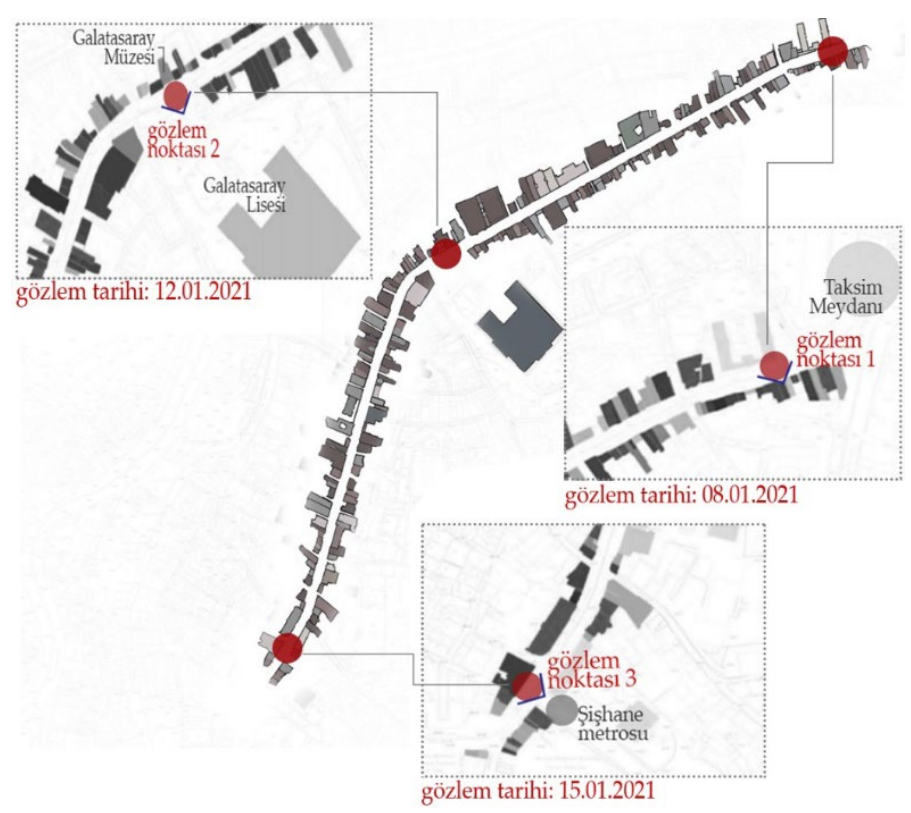

Şekil 1. Gözlem noktaları ve tarihleri (Kaynak: Yazarlar tarafından oluşturulmuştur.)

\section{Örneklem Alan Olarak İstiklal Caddesi: Sosyo-mekânsal Değişimler ve Gelişimindeki Kırılmalar}

İstiklal Caddesi; 19. yüzyılın sonlarından günümüze kadar Türkiye'nin en yoğun yaya trafiğine sahip caddelerinden biri olan, Taksim Meydanı ile Tünel Meydanı arasında bulunan 1,7 km uzunluğuyla farklılıkların bir arada bulunduğu İstanbul'un önemli kentsel alanlarından biri olmaktadır. COVID19 pandemisinin kentsel mekân ve alanları değiştiriyor olduğu düşünüldügü̈nde pandemi öncesindeki süreçleri anlamak, pandemi sürecinde gözlemlenen değişimleri detaylı bir şekilde değerlendirebilme imkânı sağlamaktadır. Bu bağlamda pandemi öncesindeki süreçler; İstiklal Caddesi'nin sosyomekânsal yapısı ve gelişimindeki kırılmalar dâhilinde cumhuriyetin ilanı öncesi, 1923-1960, 1960-1990 ve 1990-günümüz olmak üzere dört dönem üzerinden incelenmektedir (Şekil 2). 


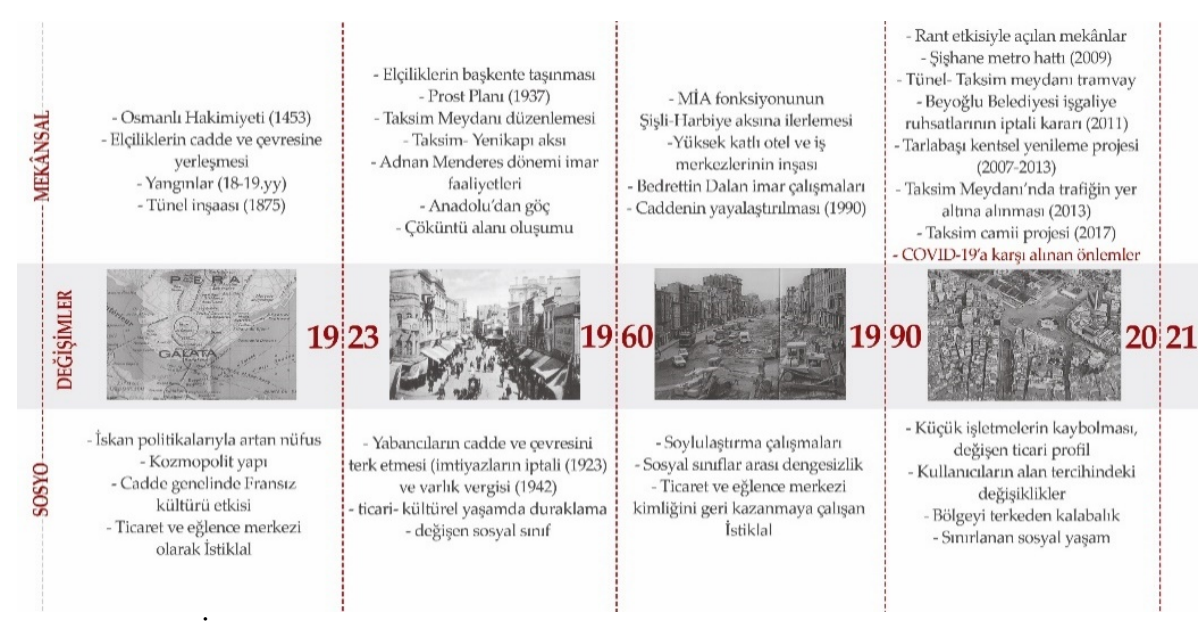

Şekil 2. İstiklal Caddesi'nin tarihsel gelişimindeki sosyo-mekânsal değişimler

\section{Cumhuriyetin ilanı (1923) öncesi}

İstiklal Caddesi; ilk kez Galata-Pera'daki surların içerisinde yaşayan Cenevizliler döneminde yoğun yabancı nüfusun ticari faaliyetler amaciyla yer edindiği bir alan olarak ortaya çıkmış, Osmanlı dönemine kadar Grande Rue de Pera olarak isimlendirilmiştir. Dökmeci ve Çıracı'ya (1990) göre İstanbul'un fethiyle birlikte Osmanlı hâkimiyetine girmiş, iskân politikalarıyla alandaki nüfus arttırılmıştır. Yerleşimin İstiklal Caddesi'ni de içine alan Pera Bağları'na doğru kayması, önceden sur içinde yer alan elçiliklerin cadde çevresinde yer edinmesine sebep olmuştur. 17-18. yüzyıla gelindiğinde Pera, Tünel ve Galatasaray arasında gelişmeye başlamıştır. 19. yüzyılda uluslararası ticaret merkezi haline gelen alanda yaşanan yangınlar, alanın yerleşim ve ticaret dokusunda önemli değişikliklere sebep olmuştur. Bu dönemdeki İstiklal Caddesi, 20. yüzyıla doğru artış gösteren kentsel düzenlemelerle günümüzdeki mevcut kentsel dokusunu almaya başlamıştır.

\section{$1923-1960$}

Cumhuriyetin ilanıyla birlikte başkentin kentleşmesine önem verilmiş, İstiklal Caddesi'ndeki birçok elçilik Ankara'ya taşınmıştır. Bununla birlikte Dökmeci ve Çıracı'ya (1990) göre bölgedeki yabancllar; verilen imtiyazların son bulması, uygulanan Varlık Vergisi ve 2. Dünya Savaşı dolayısıyla cadde ve çevresini terk etmiştir. Böylece bölgedeki otel, eğlence mekân, kafe gibi yerler eski önemini yitirmiş, ticari ve kültürel yaşam 1923-1938 yıllarında duraklama dönemine girmiştir. Bilsel ve Pinon'un (2010) kentin strüktürünü büyük ölçüde dönüştürdüğünü belirttiği Prost 1937 Planı ise İstiklal Caddesi ve 
çevresindeki kırılmaların bir diğeri olarak görülmektedir. Plan dâhilindeki Taksim Meydanı düzenlemeleri, Taksim-Yenikapı aksının açılması, Beyoğlu, Taksim, Şişli, Maçka'nun ana yerleşim bölgeleri olması gibi öneriler, cadde ve çevresindeki fiziksel dokuyu değiştirerek yoğunluğu arttırmayı hedeflemektedir. 1950'lerde ise hızlı kentleşmeden dolayı Anadolu'dan İstanbula göç eden nüfus, yabancıların terk ettiği alanlarda yer edinmiştir. Dökmeci ve Ç1racı'ya (1990) göre 1950 ve 1960 yılları arası Adnan Menderes Dönemi'nde yapılan imar çalışmalarıyla kent dokusunu etkileyen büyük yıkımlar gerçekleşmiş, bölgedeki tarihi yapılar hasar görmüş, birçok mekân alanı terk etmiş veya gelir seviyesi düşük mekânlar açılmış, değişen sosyal sınıfla birlikte kültür mekânları da yıkılarak İstiklal Caddesi ve çevresi çöküntü alanı haline gelmeye başlamıştır.

\section{$1960-1990$}

Dökmeci, Altunbaş ve Yazgı'ya (2007) göre İstanbul'un çok merkezli yapısıyla birlikte yeni gelişen bölgeler, İstiklal Caddesi ve çevresinde yaşayan ortayüksek gelir gruplarının ilgi odağı olmaya başlamıştır. 1960-1970 yıllarında, yapılan imar çalışmaları ve ekonomik desteklerle birlikte İstiklal Caddesi ve çevresinde yüksek katlı otel ve iş merkezleri yer edinmeye başlamış, böylece bölge turizmin önemli merkezi haline gelmiştir. Bölge üzerinde etkili olan diğer büyük yıkım ise 1988'de Bedrettin Dalan'ın Taksim, Tarlabaşı bölgelerinde gerçekleştirdiği müdahalelerdir. Tarlabaşı bulvarı genişletilerek alandaki konut alanları ile İstiklal Caddesi arasındaki bağlantı kesilmiş, kullanıc profilinde gelir ve eğitim düzeyi üzerinden farklılıklara sebep olmuştur.

\section{0 -günümüz}

Dönemdeki en önemli kentsel düzenlemelerden biri olan İstiklal Caddesi'nin 1990 yılında yayalaştırılması, Akın (1998) tarafından alanın yeniden canlandırılmasındaki başlıca etmenlerden biri olarak görülmektedir. Bu sayede caddenin her iki yönünde ve ara sokaklarında genç nüfusa yönelik kafe, bar, galeri gibi mekânlar açılmıştır. Ertemel (2017), yine bu dönemde Şişhane metro hattının açlması ve Tünel-Taksim meydanı arasında tramvay hattı kurgulanmasıyla cadde içerisindeki ve çevresine uzanan ulaşım bağlantılarının güçlendirildiğine vurgu yapmaktadır. Kır'a (2016) göre ise Taksim-Şişli metro hattının yoğun iş merkezine sahip olma karakterindeki Levent'e doğru uzamasiyla bu aks üzerinde tarihi dokudan kopuk olan Demirören alışveriş merkezi gibi yeni mekanlar rant etkisiyle üretilmeye başlamıştır. Bu durum, İstiklal Caddesi'ndeki küçük işletmelerin alanı terk etmesine ve buradaki ti- 
cari profilin değişmesine sebep olmuştur. Bu noktada bir diğer kırılma noktası, Beyoğlu' nun mirasını güçlendirmek ve kamu yararını korumak için zorunlu olarak başlatılan "işgaliye ruhsatlarının iptali" uygulamasıdır (Beyoğlu Belediyesi, 2011). Uygulama kapsamında İstiklal Caddesi ana omurgasının oluşturduğu kentsel dokunun etki alanındaki eğlence mekânlarının yoğunlukla bulunduğu, caddeye dik ve paralel arka sokaklardaki iş yerlerine ait masa ve sandalyeler kaldırılmıştır. Bu kullanımların düzenlemesine dair standartları içeren bir yönetmeliğin olmayışının mevcut problemlerin korunmasına, sosyalleşmeyi ve kamusallığı sınırlayan, mekân kalitesi düşük kentsel açık alanlar oluşmasına sebep olduğu düşünülmektedir. Bununla birlikte 2010 sonrası gelişen politik olaylarla birlikte gelen turist profili ve potansiyelinin değişmesi, cadde üzerindeki dükkânların işlevleri ve mekân isimleri üzerinde etkili olmuştur. Tarlabaşı'nda kentsel dönüşüm adı altında yapılan düzenlemelerin ve Talimhane bölgesinde inşa edilen otellerin yüksek gelir sınıfını bu bölgeye çekmesinin de kullanıcı profiline etki eden diğer bir faktör olduğu düşünülmektedir. İstiklal Caddesi, 2000'lere kadar özellikle genç nüfusa hitap eden kültür-eğlence merkezi fonksiyonuyla dikkat çekerken geçirdiği kültürel, ekonomik ve sosyo-mekânsal değişimler sonucunda eski kullanıcılarının Karaköy, Beşiktaş, Kadıköy gibi alanları tercih etmesiyle bu özelliğini kaybetmeye başlamıştır.

Günümüzde dünyanın hemen her yerinde güncel bir sorun olarak karş1mıza çıkan ve İstiklal Caddesi için de bir diğer kırılma noktası olarak değerlendirilebilen COVID-19 pandemisi, caddenin geçirmekte olduğu değişime yenilerini eklemekte ve bu durum önceki yıllara paralel olarak mekânsal kullanım, kullanıcı profili, kullanıcı ve aktivite çeşitliliği üzerinden okunabilmektedir. Bir sonraki başlıkta sunulan analizlerle ilişkilendirilebilecek zemin kat kullanımları incelendiğinde ticaret ve yeme-içme alanlarının cadde üzerindeki diğer kullanımlara göre baskın olduğu görülmektedir (Şekil 3).

Zemin kat kullanımlarının dağılımı ve caddenin kendi iç dinamikleri bağlamında Galatasaray Meydanı'nın, cadde boyunca yaşanan farklılaşmaların net bir şekilde gözlemlenebilmesine olanak sağlayan bir nokta olarak İstiklal Caddesi'ni, Taksim Meydanı - Galatasaray Meydanı ve Galatasaray Meydanı - Tünel Meydanı olmak üzere iki farklı alt bölgeye ayırdığı düşünülmektedir. Şekil 3 incelendiğinde her iki alt bölgede de ticari ve yeme-içme mekânlarının homojen olarak dağılmasına rağmen kültürel mekânların Galatasaray Meydanı ve Tünel Meydanı arasında daha yoğun olarak dağıldığı görülmektedir. Çam (2017), 2013-2017 yıllarında caddede en dikkat çeken değişimin kulla- 
nım dışı kalan/boş mekânlardaki artış olduğunu vurgularken bu durum günümüzde de artarak devam etmekte ve bu mekânlar özellikle Galatasaray Meydanı ve Tünel Meydanı arasında yoğunlaşmaktadır.

İstiklal Caddesi'nin pandemi öncesinde yaşadığı dönüşümlere rağmen, gündelik yaşamın içindeki akışa dâhil olan kullanıcıların cadde üzerinde çeşitli aktiviteler yoluyla bir araya gelmesiyle farklı ritimlerin temas halinde olduğu bir etkileşim alanı oluşturması, pandemi süresince alana özgü alınan önlemler ve uygulanan fiziksel sınırlandırmalarla yeni bir dönüşüm sürecine girmesi; bu alanı pandemi sürecindeki gündelik yaşam pratiklerini incelemek adına önemli kılmaktadır.

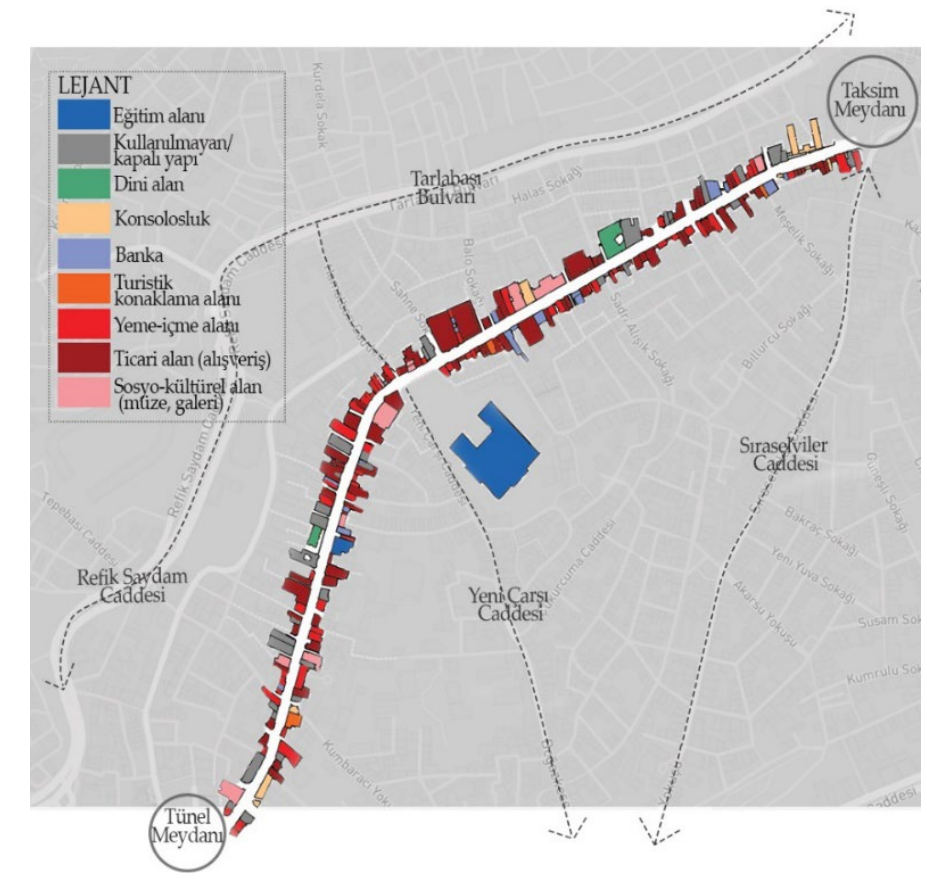

Şekil 3. İstiklal Caddesi'ndeki binaların zemin kat kullanım analizi, 2021 (Kaynak: Yazarlar tarafından oluşturulmuştur.)

\section{Pandemi Sürecinde İstiklal Caddesi'ni ve Gündelik Yaşam Pratiklerini Ritimanaliz ile Okumak}

Literatür taraması kapsamında İstiklal Caddesi üzerinde pandemi öncesi süreçte yapılmış ritimanaliz çalışmasına rastlanmaması, bu çalışma dâhilinde ritimanaliz yoluyla elde edilen pandemi sürecine ait verilerin pandemi öncesi süreç ile doğrudan karşılaştırılması konusunda çalışmayı sınırlandırmaktadır. Bu nedenle pandemi öncesinden edinilen izlenimler haricinde, o süreçte 
cadde üzerinde yapılmış, içeriği bakımından karşılaştırmalar için somut bir veri sağlayacağ 1 düşünülen ampirik çalışmalara referans verilmektedir. $\mathrm{Bu}$ bağlamda Tekin'in (2005) Beyoğlu-İstiklal Caddesi'ndeki kullanıcı-mekân ilişkilerini caddedeki kalabalık üzerinden incelediği, Altunbaş'ın (2006) İstiklal Caddesi'ndeki yayalaştırma uygulamasının caddede sebep olduğu işlevsel değişiklikleri değerlendirdiği, Özer ve Kubat'ın (2015) farklı parametreler ışığında edindiği yürünebilirlik endeksi üzerinden Beyoğlu'ndaki mevcut mekânsal yapıyı ve yaya hareketlilik dokusunu değerlendirdiği, Çam'ın (2017) İstiklal Caddesi'nin mekânsal kimlik değişimini, caddenin geçirdiği dönüşümler sonucunda değişen arazi kullanımları üzerinden incelediği çalışmalar ve bulguları kullanılmaktadır.

Bu çalışma kapsamında ise pandemi sürecine dair yapılan mekânsal analizler öncesinde bu süreçte alınan önlem ve uygulamalara değinmenin, mekânın güncel durumunu anlamak adına faydalı olacağı düşünülmektedir. Pandeminin ikinci aşaması olarak nitelendirilebilen süreci dâhilinde İçişleri Bakanlığı'na (2020a) göre ülke genelinde 30 Kasım 2020 itibariyle;

- Bütün yaş gruplarındaki bireylerin, yakın çevrede karşılanabilen zorunlu ihtiyaçlar dışında olmak şartıyla, hafta sonu (cuma günleri 21.00'da başlayıp pazartesi günleri 05.00 ' da son bulan) ve hafta içi (21.00'dan başlayıp ertesi gün 05.00 'da son bulan) sokağa çıkma kısıtlaması

- 65 yaş ve üzeri ile 20 yaş altı vatandaşların 10.00-16.00 saatlerinde şehir içi toplu taşıma araçlarını kullanmalarını içeren kısıtlama

- Yeme-içme aktiviteleri sunan işyerlerinin sadece paket ve gel-al servis şeklinde hizmet verebilmesi

- İl/İlçe Hıfzıssıhha Kurullarınca gerekli olduğu düşünülen durumlarda, simgesel özellikleri bulunan, toplanma alanı olarak kullanılan, kalabalık cadde ve meydanlarda aynı anda bulunabilecek kullanıcı sayısını sınırlandırmak amacıyla çeşitli önlemlerin alınması gibi kentsel mekânları doğrudan veya dolaylı olarak etkileyen birçok kısıtlama kararı alınarak uygulanmaya başlamıştır.

İçişleri Bakanlığı'nın (2020b) cadde ve meydanları ilgilendiren genelgesinin son maddesi kapsamında Aralık 2020 itibariyle Beyoğlu Kaymakamlığı İlçe Umumi Hıfzıssıhha Meclisi'nin kararına göre İstiklal Caddesi'nin Taksim (Şekil 4a) ve Tünel Meydanı (Şekil 4b) girişlerine güvenlik noktaları konulmuş ve çeşitli sınırlandırmalar uygulanmaya başlanmıştır. İstiklal Caddesi'nde uygulanan bu çeşitli sınırlandırmalar; 
- Kontrol altındaki kısmının 1500 metre, ortalama genişliğinin 14 metre ve toplam alanının 21000 metrekare olması nedeniyle her 3 metrekareye 1 kişi, toplam 7000 kişinin alanda aynı anda bulunabilmesi

- Cadde üzerinde sosyal mesafeyi aşan toplanmaların olduğu yerlerdeki kişilerin zabıta tarafından uyarılması

- Cadde üzerinde izinli seyyar satıciların etraflarında sosyal mesafeyi aşan toplanmalar olduğu takdirde, zabıta tarafından esnafa ait tezgâh ve araçların geçici olarak ara sokaklarda uygun noktalara alınması olarak belirtilmektedir.

Belirtilen fiziksel tedbir ve kısıtlamaların bir sonucu olarak COVID-19 pandemi sürecinin İstiklal Caddesi ve caddedeki gündelik yaşam pratikleri üzerindeki etkilerini anlamak konusunda gündelik yaşamda yapılan bireysel gözlemler eksik kalmakta ve detaylı araştırmalara gerek duyulmaktadır. Bu bağlamda çalışma kapsamında İstiklal Caddesi üzerinde çeşitli yöntemlerle yapılan araştırmaların bulguları, aktivitelere göre kullanıc yoğunluğunun oluşturduğu ritimler, cadde boyunca aktivitelerin oluşturduğu ritimler ve kullanıc çeşitliliğinin oluşturduğu ritimler olmak üzere üç başlık üzerinden incelenmektedir.
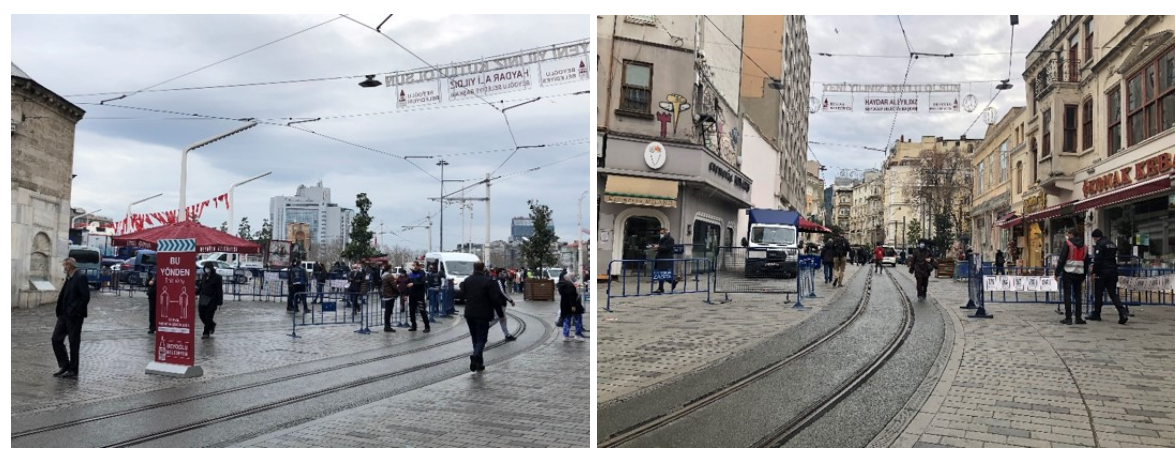

Şekil 4. Taksim Meydanı (a) ve Tünel Meydanı (b) girişlerindeki güvenlik noktaları (Kaynak: 28.12.2020 tarihinde yazarlar tarafından çekilmiştir.)

\section{Aktivitelere göre kullanıcı yoğunluğunun oluşturduğu ritimler}

Aktivitelere göre kullanıcı yoğunluğu; yöntem başlığı altında açıklandığı gibi Taksim Meydanı girişi, Galatasaray Meydanı ve Şişhane Metro istasyonu önü olmak üzere İstiklal Caddesi'nde öne çıan üç gözlem noktasında, öğlen 13.00-13.15 ve akşam 20.00-20.15 saatlerinde 15' er dakikalık yapılan video kayıtları üzerinden çift yönlü sayımlar yapılarak incelenmiştir. Bu sayımlar sonucunda öğlen saatinde 1. gözlem noktasında en yüksek yoğunluk yürüyen 
kullanıcılar tarafından oluşturulmakta iken en az yoğunluk yeterli oturma birimi olmaması sebebiyle oturmakta olan kullanıcılar tarafından oluşturulmaktadır. Diğer aktiviteler içerisinde buluşan ve ayakta bekleyen kullanıcıların oluşturduğu yoğunluk da dikkat çekmektedir (Tablo 1). Bu gözlem noktasının COVID-19 pandemisiyle birlikte Taksim Meydanı girişine yerleştirilen güvenlik ve maske -el dezenfektanı tedarik noktalarına yakınlığı, burada bu amaçlarla biriken insan yoğunluğunu arttırmakta ve bu noktanın buluşma/ bekleme noktası özelliğini pekiştirmektedir.

Öğlen ve akşam saatlerinde yapılan video kayıtlarına bakıldığında, tüm aktivitelerdeki kullanıcı yoğunluğuyla birlikte alanda oluşan ritimlerin de öğlen saatlerindekine göre azalmış olduğu dikkat çekmektedir (Şekil 5). Alandaki en az yoğunluk öğlen saatlerinin tersine buluşan kullanıcılar tarafından oluşturulurken bu durum, pandemi sebebiyle hafta içi 21.00 itibariyle uygulanan sokağa çıkma kısıtlamasıyla ilişkilendirilmektedir.

Öğlen saatleriyle benzer olarak en yüksek yoğunluk yine yürümekte olan kullanıcılar tarafindan oluşturulurken bu durum, alanın Taksim Meydanı ve çeşitli ulaşım bağlantılarına (Taksim Metro istasyonu, otobüs hatları, taksi) yakınlığ ile bağlantı kurularak açıklanmaktadır. Bu alan, akşam saatlerinde yeni ve farklı aktiviteler amaçlı buluşma ve toplanmalar için tercih edilmezken daha çok mesai bitimiyle işten çıkan veya cadde üzerinde çeşitli şekillerde vakit geçiren kullanıcıların saat sınırlaması sebebiyle pandemi öncesine kıyasla yaşam alanına daha erken dönmek durumunda kaldıkları bir geçiş noktası haline gelmektedir.

Tablo 1. Aktivitelere göre kullanıc sayı/yoğunlukları - Gözlem noktası 1: Taksim Meydanı Girişi (Kaynak: Yazarlar tarafından oluşturulmuştur.)

\begin{tabular}{lll}
\hline Öğlen (13.00-13.15) & & Akşam (20.00-20.15) \\
\hline $\mathbf{N}$ & Aktivitelere göre kullanıcılar & $\mathbf{N}$ \\
\hline 1385 & Yürüyen & 591 \\
\hline 41 & Buluşan & 0 \\
\hline 10 & Çalışan & 4 \\
\hline 3 & Oturan & 1 \\
\hline 33 & Ayakta bekleyen & 6 \\
\hline 18 & Bisiklete binen & 5 \\
\hline 8 & Elektrikli mobilete (martı vb.) binen & 2 \\
\hline 1498 & Toplam & 609 \\
\hline
\end{tabular}




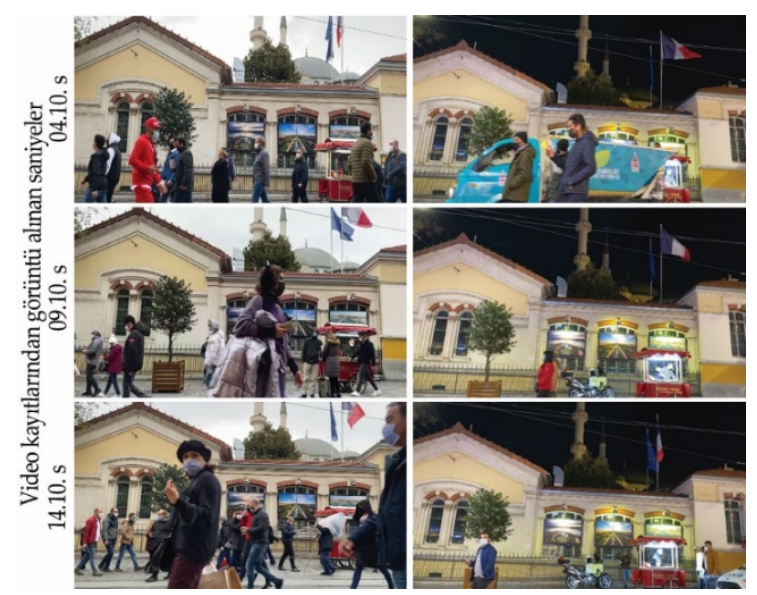

Şekil 5. Gözlem Noktası 1'den öğlen ve akşam farklı saniyelerde alınan görüntüler (Kaynak: 08.01.2021 tarihinde yazarlar tarafından çekilmiştir.)

Öğlen saatlerinde 2. Gözlem noktasına bakıldığında (Tablo 2), 1. Gözlem noktasından edinilen bulgulara benzer olarak en yüksek yoğunluk yürümekte olan kullanıcılar ile oluşturulmakta iken yoğunluğu sebebiyle göze çarpan herhangi bir kullanıcı grubu bulunmamaktadır.

Tablo 2. Aktivitelere göre kullanıc sayı/yoğunlukları - Gözlem noktası 2: Galatasaray Meydanı (Kaynak: Yazarlar tarafından oluşturulmuştur.)

\begin{tabular}{lll}
\hline Öğlen (13.00-13.15) & & Akşam (20.00-20.15) \\
\hline $\mathbf{N}$ & Aktivitelere göre kullanıcılar & $\mathbf{N}$ \\
\hline 1211 & Yürüyen & 443 \\
\hline 2 & Buluşan & 0 \\
\hline 8 & Çalş̧an & 2 \\
\hline 1 & Oturan & 0 \\
\hline 13 & Ayakta bekleyen & 4 \\
\hline 15 & Bisiklete binen & 6 \\
\hline 9 & Elektrikli mobilete (martı vb.) binen & 1 \\
\hline 1259 & Toplam & 456 \\
\hline
\end{tabular}

Akşam saatlerinde ise yürümekte olan kullanıcıların oluşturduğu ritim oldukça azalmakta, öğlen buluşan ve oturmakta olan kullanıcılar tarafından oluşturulan ritim tamamen durmakta, diğer aktiviteleri gerçekleştiren kullanıcıların oluşturduğu ritimler ise durma noktasına gelmektedir (Şekil 6). Bu anlamda bu noktanın öğlen saatlerinde yürüyen kullanıc sayısının fazlalığıyla sahip olduğu geçiş noktası olma özelliğini, akşam saatlerinde yapılan gözlemde de azalan kullanıcı yoğunluğu ve buna bağlı azalan ritim akışına rağmen koruduğu görülmektedir. 


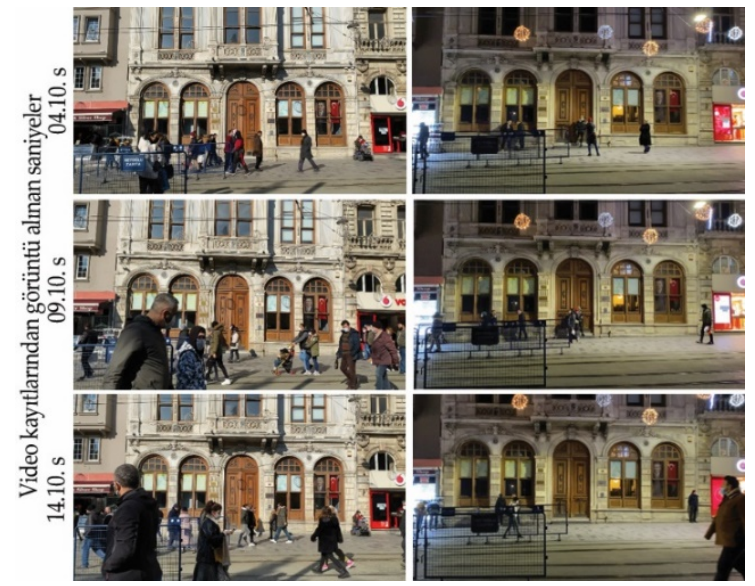

Şekil 6. Gözlem Noktası 2'den öğlen ve akşam farklı saniyelerde alınan görüntüler (Kaynak: 12.01.2021 tarihinde yazarlar tarafından çekilmiştir.)

Öğlen saatlerinde 3. Gözlem noktası incelendiğinde, yürümekte olan kullanıcıların oluşturduğu ritimler en yüksek yoğunluğu alırken oturmakta olan kullanıciların oluşturduğu yoğunluk onu takip ederek bu noktanın diğer gözlem noktalarından farklı olan bir özelliğini ortaya çıkarmaktadır (Tablo 3). Şişhane Metro istasyonu ve tünele yakınlığı ile alan sefer bekleme, buluşma amaçlı kullanılmaktadır. Pandemi sürecinde sosyal mesafe kuralları dikkate alınarak yapılan oturma birimlerinin aktif olarak kullanılması, alanda oturmakta olan kullanıcıların oluşturduğu yoğunluğun ritmini açıklar niteliktedir (Şekil 7). Bu nokta akşam saatlerinde gözlemlendiğinde, oturmakta olan kullanıcıların oluşturduğu yoğunluğun 1. ve 2. gözlem noktasındaki yoğunluğa kıyasla daha fazla olduğu görülmektedir. Bu durum, kullanıcıların pandemi sürecinde açık ve zaman geçirilebilecek alanlara olan ihtiyacına bir ipucu vererek alanda pandemi tedbirlerine uygun olarak kurgulanmış mobilyaların kullanıcıların gündelik yaşamında yer edinebildiğini göstermektedir. Buna rağmen yürümekte olan insan yoğunluğunun ritmine göre oturanların oluşturduğu yoğunluğun ritmi çok daha pasif kalmaktadır. 
Tablo 3. Aktivitelere göre kullanıcı sayı/yoğunlukları - Gözlem noktası 3: Şişhane metro istasyonu önü (Kaynak: Yazarlar tarafından oluşturulmuştur.)

\begin{tabular}{lll}
\hline Öğlen (13.00-13.15) & & Akşam (20.00-20.15) \\
\hline $\mathbf{N}$ & Aktivitelere göre kullanıcılar & $\mathbf{N}$ \\
\hline 1108 & Yürüyen & 624 \\
\hline 9 & Buluşan & 4 \\
\hline 11 & Çalş̧an & 3 \\
\hline 31 & Oturan & 8 \\
\hline 8 & Ayakta bekleyen & 3 \\
\hline 13 & Bisiklete binen & 1 \\
\hline 7 & Elektrikli mobilete (martı vb.) binen & 1 \\
\hline 1187 & Toplam & 644 \\
\hline
\end{tabular}

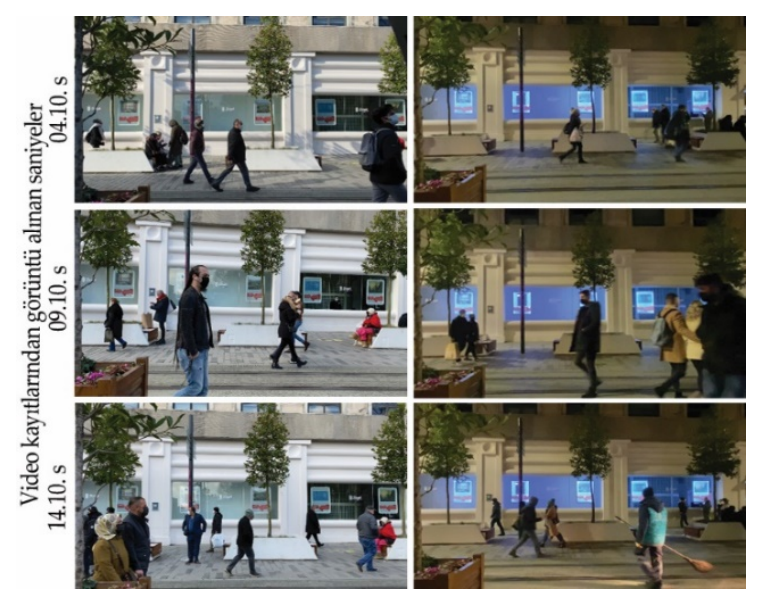

Şekil 7. Gözlem Noktası 3'ten öğlen ve akşam farklı saniyelerde alınan görüntüler (Kaynak: 15.01.2021 tarihinde yazarlar tarafından çekilmiştir.)

İncelenen üç gözlem noktası birlikte düşünüldüğünde; öğlen saatlerinde tüm aktivelerin toplamındaki kullanıc yoğunluğunun oluşturduğu ritimler en çok gözlem noktası 1, en az ise gözlem noktası 3'de gözlemlenmektedir. Akşam saatlerine bakıldığında ise, daha farklı bir durum olarak 3. gözlem noktasının en fazla, 2. gözlem noktasının ise en az yoğunluğu sahip olduğu görülmektedir. Pandemi öncesinde Altunbaş'ın (2006) yaptığı çalışmaya göre caddede Şişhane Metrosu-Tünel Meydanı girişindeki yaya yoğunluğu, çalışmadaki diğer sayım noktalarına (Taksim Meydanı girişi ve Galatasaray Meydanı) göre hem gündüz hem akşam saatlerinde daha az gözlemlenmektedir ve bunun sebebi alanda çoğunlukla resmi kurumlar ve iş servislerinin olmasıyla ilişkilendirilmektedir. Bu anlamda pandemi öncesine kıyasla pandemi sürecinde 3. gözlem noktasında öğlen saatlerinde yaşanan farklılık dikkat çekmektedir. Bu durum, Şişhane Metrosu çevresindeki konut yoğunluğunun 
diğer iki noktanın çevresindekine göre daha fazla oluşu ve burada yaşayan kullanıcıların alanın yürüme mesafesinde oluşundan dolayı sokağa çıkma k1sttlamasına dâhil olmadan vakit geçirebilmeleri ile açıklanabilmektedir. Bu ve benzeri farklılıklar, akşam 21.00 sokağa çıkma kısıtlaması öncesinde ulaşım bağlantıları, konut-iş yeri çevrelerine yakınlık; öğlen ise yeme-içme gibi ticaret fonksiyonları ile ilişkilendirilebilmektedir. Özer ve Kubat (2015), pandemi öncesi İstiklal Caddesi'nde yaya hareketlerinin (yürüme) en baskın pratik olarak gözlemlendiğine değinmektedir. Pandemi öncesindeki bu duruma referansla her üç gözlem noktasında en yüksek yoğunluğun yürümekte olan kullanıcılar tarafından oluşturulması, caddenin bu özelliğini kaybetmediğini göstermektedir.

\section{Cadde boyunca kullanıcı çeşitliliğinin oluşturduğu ritimler}

İstiklal Caddesi'nin Taksim ve Tünel Meydanı girişi arasında, 08.01.2021 tarihinde öğlen saat 12.30-12.47 ve akşam 19.30-19.47 saatlerinde gerçekleştirilen 17 'şer dakika süren iki yürüyüş, cadde üzerindeki kullanıcı çeşitliliğinin oluşturduğu ritimleri ortaya koymayı amaçlamaktadır. Elde edilen bulgular ışı̆̆ında İstiklal Caddesi'nde öğlen saatlerinde sokak satıcıları, seyyar satıc1lar, milli piyango satıcıları, pandemi dolayısıyla yerleştirilen kontrol noktalarındaki yetkililer gibi farklı kullanıcıların bir arada olduğu görülmektedir (Şekil 8a). Öte yandan Tekin (2005), pandemi öncesi süreçte İstiklal Caddesi'ndeki kalabalığı oluşturan "cumartesi anneleri" gibi direniş gruplarının ve caddenin kültürel yapısına katkı sağlayan sokak sanatçılarının varlığı üzerinde durmaktadır. Günümüz pandemi koşullarında uygulanan sınırlandırmalar ile birlikte bu kullanıcılara rastlanamadığı görülmektedir. Bu anlamda pandemi sürecinde caddede kullanıcı çeşitliliğinin oluşturduğu ritmin azalarak değiştiği ve bunun sonucunda alanın kimliğinin de etkilendiği söylenebilmektedir. 


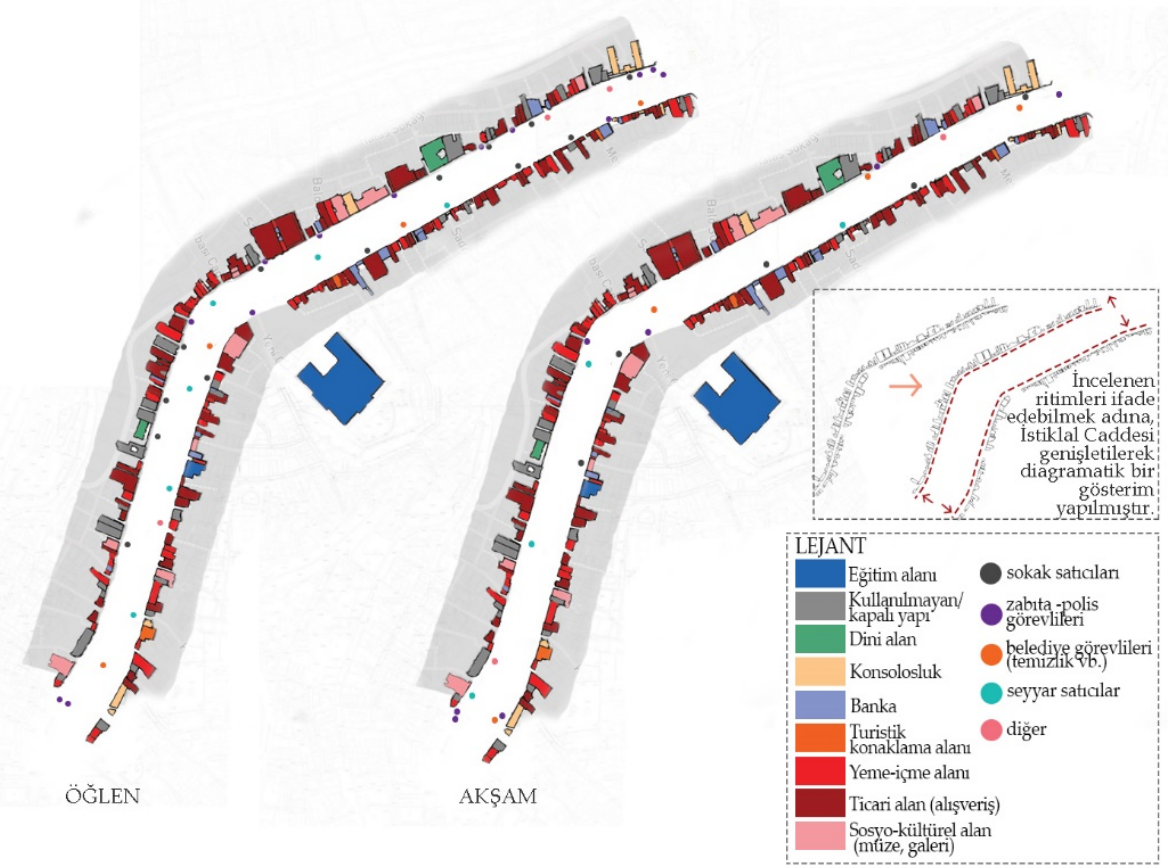

Şekil 8. Öğlen (a) ve akşam (b) kullanıcı çeşitliliğinin oluşturduğu ritimler (Kaynak: Yazarlar tarafından oluşturulmuştur.)

Cadde üzerindeki bu farklı kullanıcı tipleri, etrafına başka kullanıcıları da çekerek caddenin hareketliliğini sağlamaktadır; fakat alınan pandemi önlemleri dâhilinde cadde üzerindeki izinli seyyar satıcıların etrafındaki toplanmaların yetkililer tarafında uyarılarak dağıtılması bu hareketliliğin oluşmasında engel oluşturmaktadır. Akşam saatlerinde ise (Şekil 8b), saat 21.00 itibariyle başlayan sokağa çıkma kısıtlaması sebebiyle özellikle caddede çalışma amaçlı bulunan farklı kullanıcıların alandan pandemi öncesine kıyasla daha erken ayrılmak durumunda kalması cadde üzerindeki kullanıcı çeşitliliğinin oluşturduğu ritim akışının yavaşlamasıyla sonuçlanmaktadır (Şekil 9). Alanda yapılan gözlemler kullanıcı-mekân (bina zemin kat kullanımı) ilişkisi bağlamında düşünüldügüünde; sokak satıcılarının, kullanılmayan/pandemi dolayısıyla işlev dışı kalan yapı ve dükkân önlerindeki eşiklerde kendine yer edinmiş olduğu göze çarpmaktadır. 

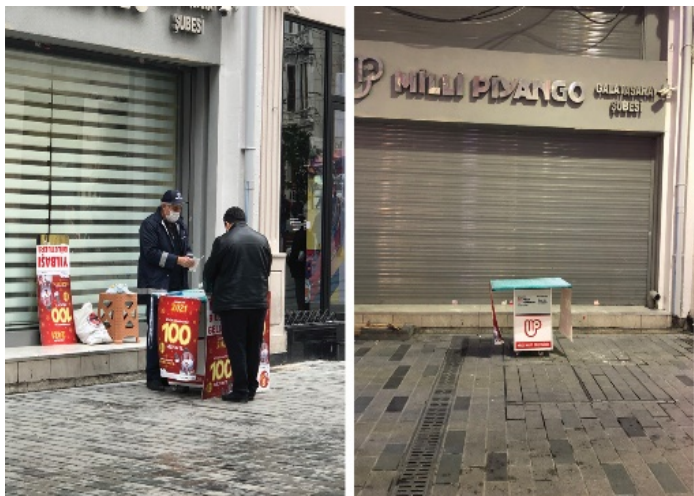

Şekil 9. Öğlen (a) ve akşam (b) kullanıcı çeşitliliğindeki farklılık (Kaynak: 08.01.2021 tarihinde yazarlar tarafından çekilmiştir.)

\section{Cadde boyunca aktivitelerin oluşturduğu ritimler}

Kullanıcı çeşitliliğinin oluşturduğu ritimlerin gözlemlendiği bu iki yürüyüş, aynı zamanda cadde üzerinde pandemi ve buna bağlı alınan tedbirler kapsamında değişen akıştaki ritimleri ortaya koymaktadır. Kullanıcı hareket ve davranışlarının caddedeki giriş kat arazi kullanımları ile ilişkisi, davranışsal haritama ile incelenmektedir. Bu incelemeden elde edilen bulgular doğrultusunda cadde boyunca akışı değiştirmede rol oynayan kafe ve restoran gibi yeme-içme fonksiyonları, bankalar, eğitim alanları, boş yapılar veya kapalı dükkânlar öne çıkmaktır. Öğlen ve akşam saatlerindeki genel ritim akışı karşılaştırıldığında, öğlen saatlerinde bazı transfer ve odak noktaları başta olmak üzere bu öne çıkan alan ve fonksiyon çevrelerinde daha yoğun ve hızlı bir ritim gözlemlenmektedir (Şekil 10a ve 10b). Bunun bir sebebi, alandaki yemeiçme aktivitelerindeki ve sosyo-kültürel etkinliklerdeki çeşitliliğin bu alanlarda uygulanan çeşitli kısıtlamalara rağmen özellikle yakın çevrelerde yaşayan kullanıcıların alternatif çözümler üreterek alanı kullanmayı tercih etmelerine sebep olmasıdır. Bir diğer sebebi ise cadde üzerinde ve çevresinde yer alan çalışma alanlarının çokluğu ve buna bağlı olarak seçilen gözlem saatinin öğle arasına denk gelmesi ile çalışmakta olup öğle arasına giren kesimin, yeme-içme, dinlenme, diğer boş zaman aktiviteleri gibi sebeplerle İstiklal Caddesi'ne gelerek cadde akışındaki ritmi arttırmasıdır. 


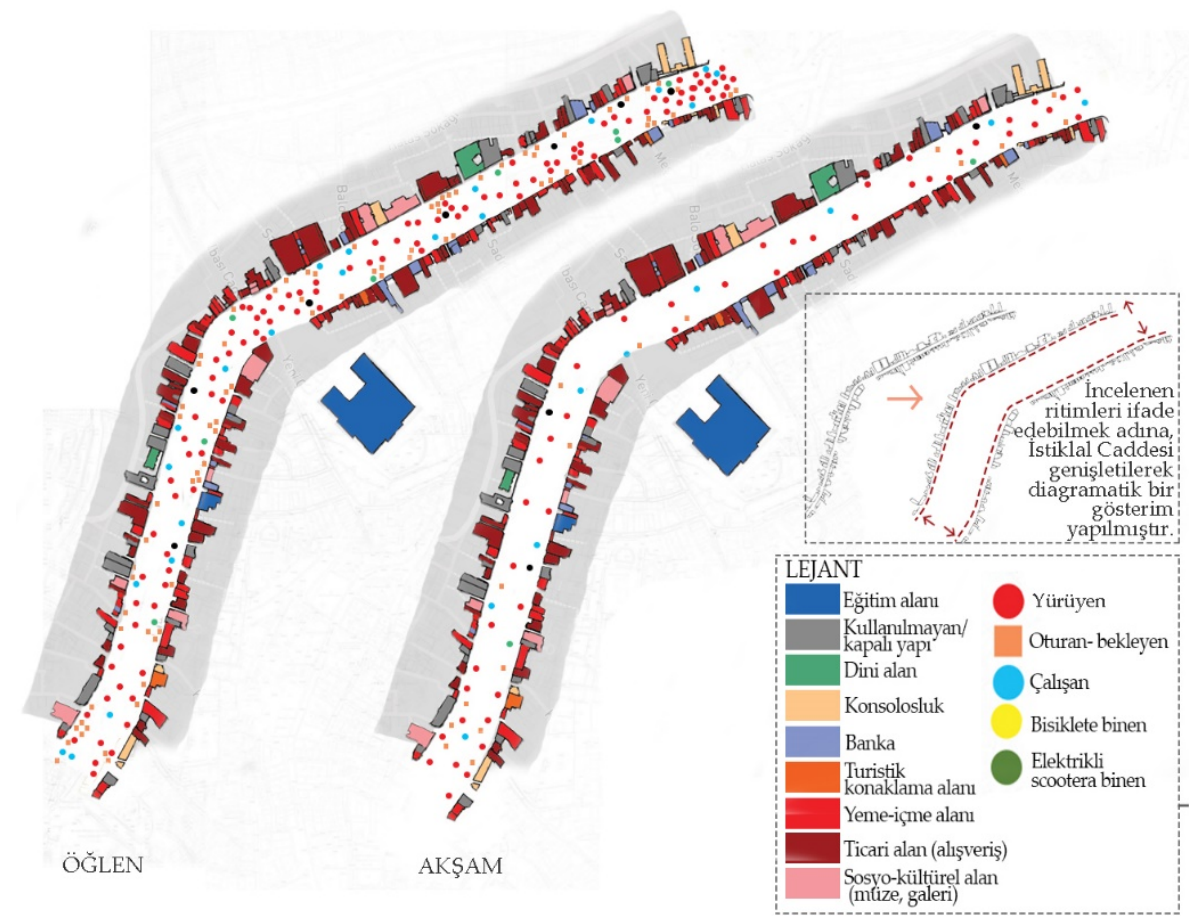

Şekil 10. Öğlen (a) ve akşam (b) aktivitelerin oluşturduğu ritimler (Kaynak: Yazarlar tarafından oluşturulmuştur.)

Akşam saatlerinde ise 21.00 itibariyle başlayan sokağa çıkma kısıtlamasının kullanıcı davranışları ve cadde boyunca oluşan ritimler üzerinde olumsuz etkileri olmakta ve cadde kullanımında değişiklikler görülmektedir. Buna bağlı olarak ritimler birçok noktada belirli sürelerde durma noktasına gelmekte ve hatta durmaktadır. Çam'ın (2017) pandemi öncesindeki çalışma bulgularına göre İstiklal Caddesi'nde daha çok yeme-içme, eğitim aktiviteleri, alışveriş, turistik etkinlikler baskınken pandemi süresince bu durum öğlen saatlerinde azalarak farklı şekillerde de olsa devam etse de akşam saatlerinde alanın tercihten ziyade güçlü ulaşım bağlantılarından dolayı transfer merkezi olma, çalışma alanlarına yakınlık gibi zorunlu sebeplerle kullanıldığı görülmektedir.

$\mathrm{Bu}$ incelemeler amaciyla cadde boyunca yapılan yürüyüşlerden edinilen gözlemler; sahip olduğu hareketlilik, devinim ve canlılık ile ritmik bir alan olan İstiklal Caddesi'ndeki tekli ritimleri ortaya koymak dışında, çoklu ritimlerin etkileşim biçimleri ile ilgili yorum yapmaya da olanak sağlamaktadır. Kentsel ritimler bölümünde tanımlanmış çoklu ritimlerin etkileşim biçimleri 
çalışma alanı üzerinden düşünüldüğünde farklı ritimlerin uyumsuzluk olmaksızın bir arada bulunması durumu, cadde üzerindeki en baskın pratik olan yaya hareketlerinin oluşturduğu sürekli ritimler olarak karşlık bulmaktadır (Şekil 11).
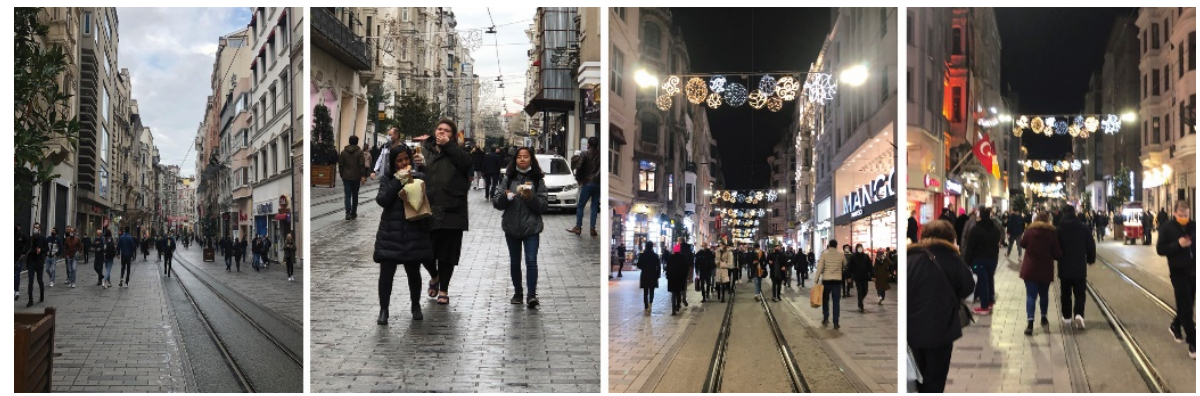

Şekil 11. Farklı ritimlerin uyumsuzluk olmaksızın bir arada bulunması durumuna örnekler (Kaynak: 08.01.2021 tarihinde yazarlar tarafından çekilmiştir.)

Birden fazla ritmin uyumlu bir şekilde bir arada bulunmasındaki etkileşim durumuna İstiklal Caddesi özelinde bakıldığında pandemi süresince uygulanan çeşitli sınırlamalar kapsamında yeni davranış biçim ve gündelik yaşam pratikleri ortaya çımaktadır (Şekil 12). Bu sınırlamalar ile kullanıcıların kentsel mekân ile kurduğu ilişki değişmekte ve bu durum onları mekânı yeniden üretme hali içerisine itmektedir. Pandemi sürecinde yeme-içme mekânlarının paket ve gel-al servis dişında hizmet vermemesi; kullanıcıların, bina zemin kat analizinde görünen yeme-içme mekânlarının giriş alanlarında veya kullanılmayan/kapalı mekânların eşiklerinde sosyal mesafeli bir şekilde kümelenmesine sebep olarak yeni, anlık kamusallıklar oluşturmaktadır. Benzer olarak pandemi sürecindeki sınırlamaların oturma- zaman geçirme gibi faaliyetlere olanak sağlayan açık alanların eksikliğiyle birleşmesi sonucunda, kullanıcılar tarafından tramvay durağı veya cadde üzerindeki peyzaj öğeleri gibi mekân ve elemanlara mevcut fonksiyonlarından farklı fonksiyonlar verilmeye başlanmıştır. Bu yeni fonksiyonlar, öncekilerden farklı olsa da onlarla bir arada bulunabilmektedir. Böylece mekân işlevlerinin dönüşmesiyle olağanüstü bir durum olarak kabul edilen pandemi süresince geçici olduğu düşünülen ritimler ortaya çıkmaktadır. 

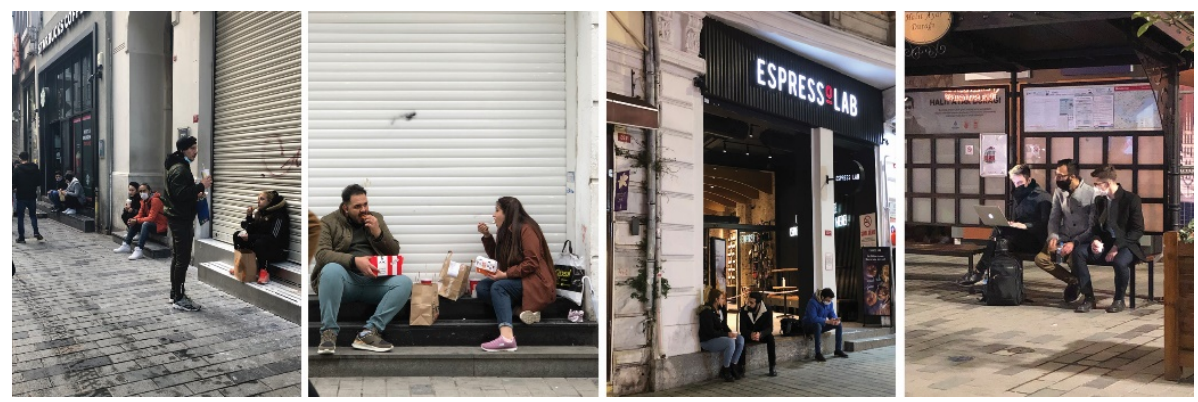

Şekil 12. Birden fazla ritmin uyumlu bir şekilde bir arada bulunmasındaki etkileşim durumuna örnekler (Kaynak: 08.01.2021 tarihinde yazarlar tarafından çekilmiştir.)

Birden fazla ritmin uyumsuz bir şekilde bir arada bulunması durumu, baskın pratiklerin oluşturduğu ritimlerde kopukluklara sebep olacak şekilde oluşmaktadır. İstiklal Caddesi'ne bakıldığında pandemi sürecinde alınan k1sttlamalardan biri olarak banka, alışveriş merkezi ve yeme-içme mekânlarının içeriye belirli bir sayıdan fazla kullanıcı kabul etmemesi, bu mekânların önünde bekleyen insanlardan oluşan sıraların uzayarak devam etmesine ve cadde üzerindeki sürekli ritim akışında kopmalara sebep olmaktadır (Şekil 13).
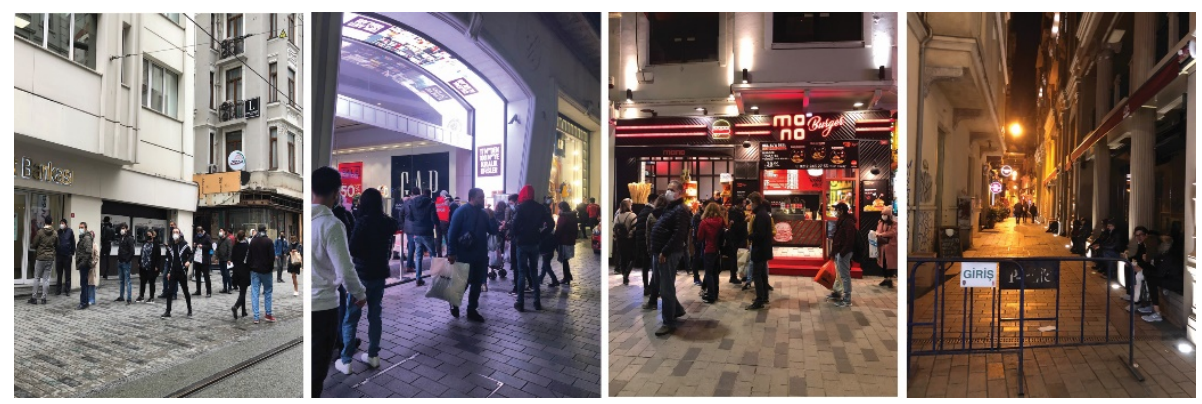

Şekil 13. Birden fazla ritmin uyumsuz bir şekilde bir arada bulunması durumuna örnekler (Kaynak: 08.01.2021 tarihinde yazarlar tarafından çekilmiştir.)

İstiklal Caddesi'nin gelişim sürecinde rant etkisiyle üretilen mekânlardan biri olan Demirören alışveriş merkezi, sahip olduğu alanın büyüklügü ve tüketim odaklı alışkanlıklara sahip kullanıcılar tarafından pandemi sürecinde de tercih edilmesi ile öne çıarak her iki gözlem saatinde ritim akışını kesintiye uğratması yönüyle dikkat çekmektedir. Bununla birlikte ritimler arasında uyumsuzluğa sebep olan diğer bir etken ise, pandemi süresince alınan önlemlerden biri olarak sokakların İstiklal Caddesi'ne bağlanan noktalarına 
yerleştirilen kontrol bariyerleri olmaktadır. Özellikle İstiklal Caddesi'ne yoğun akışın olduğu sokaklarda bu bariyerler, caddedeki ritim akışını keserek uyumsuzluk yaratmaktadır.

\section{Tartışma ve Sonuç}

Çok boyutlu bir yapıya sahip olan, tarihsel süreçte gelişen olaylar ile değişerek dönüşüme uğrayan kentsel mekân; günümüzde tüm dünyayı etkisi altına almış, en önemli sağlık sorunlarından biri olan COVID-19 pandemisinin etkisi altına girmiş durumdadır. Pandeminin etkisiyle değişmekte olan kentsel mekânlar ve buna bağlı olarak dönüşen gündelik yaşam, insan ve mekân arasında kurulan ilişkilerin farklı ölçeklerde yeniden biçimlenmesine sebep olmaktadır. Bu süreçte sorunları, potansiyel ve farklı dinamikleri anlamlandırarak sözü edilen yeniden biçimlenmeleri analiz edebilmek; COVID-19 süreci ve sonrasındaki olası senaryolar, tasarım ve planlama yaklaşımlarını kurgulamak açısından önem teşkil etmektedir. Bu süreci analiz etmek adına farklı ve kapsamlı yöntem arayışları devam ederken kentsel mekânı ve gündelik yaşam pratiklerini süreç içerisinde inceleyen "ritimanaliz", bu çalışmanın ana metodolojisini oluşturmaktadır. Ritim, kentsel ritim, ritimanaliz kavram ve kapsamlarl; yerel ve hatta küresel anlamda önemli bir kentsel kamusal alan ve örneklem olduğu düşünülen İstiklal Caddesi üzerinden incelenerek pandemi sürecinde alanın ve buradaki gündelik yaşam pratiklerinin nasıl etkilenmiş olduğu COVID-19 öncesinden edinilen izlenimler ve yapılmış olan literatür çalışmaları çerçevesinde yorumlanarak tartışılmaktadır.

Gözlem, video kayıt ve davranışsal haritalama araçları kullanılarak farklı gün ve saatlerde edinilen veriler doğrultusunda Taksim Meydanı girişi, Galatasaray Lisesi ve Şişhane Metro istasyonu önü olmak üzere alınan üç gözlem noktasında aktivitelere göre kullanıcı yoğunluklarında farklılıklar yaşandığı görülmektedir. Öğlen ve akşam saatlerine göre mekân kullanım ve fonksiyonlarının değiştiği, öğlen aktif buluşma, bekleme veya zaman geçirme fonksiyonlarına sahip bir alanın akşam saatlerinde tamamen bir geçiş/transfer noktasına dönüştügü izlenmektedir. Bu durum; pandemi sürecinde uygulanan saat 21.00 itibariyle başlayan sokağa çıkamama, kafe/restoran benzeri yeme-içme yerlerinin paket ve al-götür dışında servis vermemesi, bankalar ve alışveriş alanlarında aynı anda bulunabilecek kişi sayısı limitleri gibi sınırlandırmalardan kaynaklı olduğu şeklinde yorumlanmaktadır. İş yerlerinin veya bireysel çalışanların çalışma ve aynı zamanda eğitim şartlarında pandemi dolayısıyla yapılan değişiklikler, saat sınırlamaları; çalışan ve öğrenci hareketliliğini azaltarak olu- 
şan ritimleri negatif yönde etkilemektedir. Benzer şekilde kentsel mekânın konumu, ulaşım bağlantıları, çalışma ve konut çevrelerine yakınlığı etkili olan diğer etmenler olarak siralanabilmektedir.

Pandemi öncesindeki çok çeşitli kullanıc yapısına sahip olan cadde, bu özelliğini kaybetmekte kullanıcı çeşitliliğinin oluşturduğu ritimler ise değişmektedir. Bu yönüyle pandeminin kullanıcıların belleğinde canlanan kentsel mekân algısını da değiştirebildiği söylenebilmektedir.

Aktivitelerin oluşturduğu ritimler çerçevesinde çoklu ritimlerin bir aradalığına bakıldığında kullanıcı-kentsel mekân ilişkilerinin yeniden tanımlandığı görülmektedir. Pandemi dolayısıyla alınan önlemler kapsamında pandemi öncesinde çoğunlukla kapalı, yarı kamusal mekânlarda zaman geçirmeye dayalı alışkanlıklara sahip kullanıcılar, açık mekân ihtiyacıyla birlikte sokağ 1 yeniden üretme hali içine girmeye başlamıştır. Pandemi öncesinde "içeri"de gerçekleştirilen faaliyetlerin, zorunlu pandemi şartları dolayısıyla "dışarı" taşınması, olağan kentselliklerin anlık ve rastlantısal üretimini getirmektedir. Kullanıcilar tarafından oluşturulan bu alternatifler, kentsel mekânların geleceği üzerine eleştirel bir pencere açmakta, İstiklal Caddesi'ndeki yeni olası kullanımları tartışarak geleceğe yönelik plan ve tasarım önerileri sunmaya imkân sağlamaktadır. Bu bağlamda;

- Pandemi süresince kullanıcılar tarafından cadde üzerindeki eşik mekânlarda oluşturulan alternatif kullanımların esnekliği, yer oluşturma bağlamında değerlendirilerek bütüncül tasarım ilkeleri oluşturulmalıdır.

- Caddede yaşanan değişimlerin geçicilik potansiyeli çerçevesinde, taktiksel şehircilik gibi kısa süreli ve az maliyetli, değişimi destekleyen aşamalı yaklaşımlar benimsenmelidir.

- Cadde üzerinde yetersiz kalan fiziksel elemanlar (oturma birimleri, peyzaj ögeleri) arttırılarak sürekli hale getirilmeli ve bu elemanların kullanıcılara farklı aktiviteler sağlaması desteklenmelidir.

- Cadde, kendi içindeki dinamikler haricinde yakın çevre ilişkileriyle birlikte düşünülerek olası afet koşullarına uyarlanabilir ulaşım bağlantıları sağlanmalıdir.

Sonuç olarak İstiklal Caddesi; tarihi boyunca geçirdiği sosyo-mekânsal değişimler, tanıklık ettiği kentsel dönüşüm projeleri ve uygulamaları ile dönüşüm içindedir. Bu çerçevede cadde; kent içerisinde yeme-içme, turizm, ticaret, sosyo-kültür fonksiyonlarıyla öne çıkan bir zaman geçirme mekânı olmaya devam etse de günden güne kullanıc kitlesini kaybetmekte, sunduğu aktivite çeşitliliği, kullanıcı profili ve sahip olduğu açık mekânların kalitesiyle 
kentteki Karaköy, Beşiktaş, Kadıköy gibi diğer semtlere göre geri planda kalmaktadır. Çalışma kapsamında yapılan analizlerde görüldüğü üzere pandemi olgusunun kentsel mekân ve gündelik yaşamda yarattığı değişiklikler, pandemi öncesinde zaten yaşanıyor olan değişim ve dönüşümlerin etki alanını genişleterek benzer sonuçlara sebep olmaktadır. Pandemi sebebiyle süregelen bu değişiklikler; geçicilikler üzerinden kentsel ritimlerdeki kırılma, kopma ve bozulmalara yol açmaktadır. "Pandemi sonrası" olarak nitelendirilebilecek dönemde, bu ritimsel bozulmalarının bir kısmı büyük ölçüde eski haline dönecek olsa da olası pandemi veya benzeri afet durumlarına karşı kapsamlı, kullanıcıların ihtiyaçlarına uygun, geçici ve kolay çözüm önerileri hazırlanmalıdır. Alışılagelmiş mekân kullanım ve tüketim biçimleri yeniden düşünülerek kullanıcıların gündelik yaşam pratikleri ve davranış biçimleri kentsel ritimler üzerinden izlenmeli, pandemi öncesindeki kentsel mekânların aynı işlevsellikte kullanılmaya devam edip edemeyeceği sorgulanmalıdır. 


\section{Extended Abstract}

\section{Reading Urban Space and Practices of Everyday Life through Rhythmanalysis during the Pandemic: The Case of Istiklal Street}

\author{
Burcu Soygüzeloğlu \\ ORCID: 0000-0001-7113-5189
}

\author{
Eren Kürkçüoğlu \\ ORCID: 0000-0002-3723-9803
}

Urban spaces with their complex and multi-dimensional structure have been affected by various important events in the historical process such as the industrial revolution, globalization, developments in communication, and information technologies. In addition to these events, another factor that changes and transforms urban spaces is pandemics that spread over wide geography without knowing borders, affecting individuals, their routines and habits, the relationship between individuals and urban spaces, societies, and practices of everyday life. Today, the COVID-19 outbreak, which is predicted to have started in $\mathrm{Wu}-$ han, in the People's Republic of China in December 2019, has spread to the other countries and cities in short time. Because of the problems coming with this pandemic urban spaces, the practices of daily life, and how they will be reshaped after the pandemic have become subjects of debate, and different and comprehensive methods have been needed in this regard. In this sense, it is considered that the concept of "rhythmanalysis", examined in Lefebvre's book "Rhythmanalysis: Space, Time and Everyday Life", published in 2004, is an important method in terms of being process-driven. This study aims to examine the concept of urban rhythms as a product of the relationship between urban space and the practices of daily life, the scope of rhythmanalysis, and to analyze the urban space and the practices of daily life during the COVID-19 through urban rhythms. Within the scope of the study the method of rhythmanalysis, defined theoretically, is implemented in the case of Istiklal Street, considered to be a significant area in terms of its historical background and highly interactive structure by observing, using video recording, and behavioral mapping. In this context this street and 
the practices of daily life are examined under three headings, rhythms created by the density of users according to activities, rhythms created by the diversity of users, and rhythms created by the activities, respectively. While these headings are being examined, the cyclical rhythms mentioned in the literature review are discussed over two different time zones, evening and noon during the day. Within the first heading video recordings are taken from three observation points on three different days, at 1-1.15 p.m. and 8-8.15 p.m. These three observation points -Taksim Square entrance, Galatasaray High School, and Şişhane Metro stationare determined by considering the character and uses of Istiklal Street before and during the pandemic. Two-way countings are made over these video recordings, and the rhythms created by the density of users according to activities are measured. As a result of this analysis, it is observed that the use and the functions of the observation points change according to the observation hours (noon and evening), and the points used for the aim of the active meeting, waiting, or spending leisure time at noon turns into a transition/transfer point in the evening. The restrictions imposed during the COVID-19 such as the fact that the number of people being in places (banks and shopping malls) at the same time is limited, cafes and restaurants are not able to provide other services except for take-away, and people are not able to go out after 9 p.m are considered as a reason of this situation. Changes in working hours and circumstances of education affect the mobility of working people and students negatively, thus rhythms created by those users of the street have started to reduce in the street. Similarly, the location of the street and its proximity to the transportation network, workplaces, and residential areas can be listed as the other influential factors.

The other two headings, the rhythms created by the diversity of users and activities along the street are evaluated separately over the changing flow within the scope of the pandemic on the street and the measures taken accordingly. Two different walks throughout Istiklal Street (from Taksim Square entrance to Tünel Square entrance) are carried out at 1.30-1.47 p.m. and 7.30-7.47 p.m. Due to the data obtained from them, the behavioral pattern of the users is analyzed by using behavioral mapping and interpreted by considering the land-use analysis of the area. It is seen that the rhythms created by the diversity of users in Istiklal Street have also changed, and the street, which has a wide variety of users before the pandemic is faced with losing its feature. Therefore, the pandemic can change the perception of urban space in the users' memory.

Within the framework of the analysis for the rhythms formed by the activities along the street, the flow of rhythms at noon and evening hours are compared, and more intense and rapid flow is observed in some focal and transfer points 
and their surrounding at noon. In line with these findings, functions of food and beverage such as cafes and restaurants, banks, education areas, empty buildings/closed shops stand out in changing the flow along the street.

The results attained from this study in Istiklal Street, are considered as a clue for the future of urban spaces. Ongoing changes in urban space and daily life due to pandemics cause breakage, ruptures, and deterioration in urban rhythms. Even though some of these rhythm disturbances may return to their previous state with the end of the pandemic, comprehensive, temporary, and practical solutions should be prepared for the possible pandemics or the other disaster scenarios in the post-COVID-19 era. Whether urban spaces can continue to be used with the same functionality before the pandemic should be questioned by rethinking the usual spatial uses and the consumption patterns in cities through urban rhythms.

\section{Kaynakça/References}

Akın, N. (1998). 19. yüzylln ikinci yarısinda Galata ve Pera. İstanbul: Literatür Yayınları. Altunbaş, U. (2006). Kent merkezlerinde yayalaştırmannn işlevsel değişim üzerine etkileri: İstiklal Caddesi örneği (Yüksek lisans tezi). İstanbul Teknik Üniversitesi, Fen Bilimleri Enstitüsü, İstanbul.

Aslan, R. (2020). Tarihten günümüze epidemiler, pandemiler ve Covid-19. Ayrntı Dergisi, 8(65), 35-41.

Beyoğlu Belediyesi Faaliyet Raporu (2011). 29 Mayıs 2021 tarihinde http://webarsiv.beyoglu.bel.tr/ adresinden erişildi.

Bilsel, C. ve Pinon, P. (2010). İmparatorluk başkentinden Cumhuriyet' in modern kentine: Henri Prost'un İstanbul planlaması (1936-1951). İstanbul: İstanbul Araştırmaları Enstitüsü Kataloglan, 73-150.

Cihanger Ribeiro, D. (2019). The poiesis of everyday life and space in Yüksel Street. Journal of Ankara Studies, 7(1), 1-25.

Çam, S. (2017). The impacts of land-use change on place identity: The case of Istiklal Street (Yüksek lisans tezi). İstanbul Teknik Üniversitesi, Fen Bilimleri Enstitüsü, İstanbul.

Çiçek, S. (2021). An evaluation model for the resilience of public spaces during Covid19 pandemic. JCoDe: Journal of Computational Design, 2(1), 313-334.

Dökmeci, V. ve Çıracı, H. (1990). Tarihsel gelişim sürecinden Beyoğlu. İstanbul: Türkiye Turing ve Otomobil Kurumu Yaymları.

Dökmeci, V., Altunbas, U. ve Yazg1, B. (2007). Revitalization of the main street of a distinguished old neighbourhool in Istanbul, European Planning Studies, 15(1), 153166.

Elden, S. (2004). Rhythmanalysis: An Introduction. H. Lefebvre, Rhythmanalysis: Space, Time and Everyday Life içinde (ss. 1-12). New York: Continuum. 
Erdönmez, M.E. ve Akı, A. (2005). Açık kamusal kent mekânlarının toplum ilişkilerindeki yeri. MEGARON YTÜ Mim. Fak. E-Dergisi, 1 (1), 67-87.

Ertemel, E. (2017). Galata Sur İçi Bölgesinin kent dokusu ve anıtsal yapı bağlamında tarih süreç içerisindeki gelişimi ve değişiminin izlenmesi (Yüksek lisans tezi). Mimar Sinan Güzel Sanatlar Üniversitesi, Fen Bilimleri Enstitüsü, İstanbul.

Gümüş, İ. ve Yılmaz, E. (2020). Rhythmanalysis as a method of analyzing everyday life spaces: the case of Kibrıs Şehitleri Street in İzmir. Online Journal of Art and Design, 8(3), 229-250.

İçişleri Bakanlığı. (2020a). Koronavirüs ile Mücadele Kapsamında - Yeni Kısıtlama ve Tedbirler Genelgeleri. 3 Ocak 2021 tarihinde https://www.icisleri.gov.tr/koronavirus-ile-mucadele-kapsaminda-sokaga-cikma-kisitlamalari---yeni-kisitlamave-tedbirler-genelgeleri adresinden erişildi.

İçişleri Bakanlığı. (2020b). 81 ile Cadde, Bulvar, Meydan Tedbirleri Genelgesi. 3 Ocak 2021 tarihinde https:/www.icisleri.gov.tr/81-ile-cadde-bulvar-meydan-tedbirleri-genelgesi adresinden erişildi.

James, A. C. (2020). Don't stand so close to me: Public spaces, behavioral geography, and Covid-19. Dialogues in Human Geography, 10(2), 187-190.

Kasinitz, P. (2020). Rending the "cosmopolitan canopy": Covid-19 and urban public space. City \& community, 19(3), 489-495.

Kır, A. (2016). Kentsel bellek mekânı olarak sokaklar: İstiklal Caddesi örneği (Yüksek lisans tezi). İstanbul Teknik Üniversitesi, Fen Bilimleri Enstitüsü, İstanbul.

Lefebvre, H. (2004). Rhythmanalysis: Space, time and everyday life. New York: Continuum.

Lefebvre, H. ve Regulier, C. (2004). The Rhythmanalytical project. H. Lefebvre, Rhythmanalysis: Space, Time and Everyday Life içinde (ss.71-83). London, New York: Continuum publishers.

Marcus, L. (2014). Rhythm-studies. Music and Architecture, 6-14.

Marcu, S. (2017). Tears of time: a Lefebvrian rhythmanalysis approach to explore the mobility experiences of young Eastern Europeans in Spain. Transactions of the Institute of British Geographers, 42, 405-416.

O'Connor, E. (2020). Public space plays vital role in pandemic. 1 Haziran 2021 tarihinde https:/gehlpeople.com/blog/public-space-plays-vital-role-in-pandemic/ adresinden erişildi.

Özer., Ö. ve Kubat., A.S. (2015). Measuring walkability in Istanbul Galata Region. Journal of ITU AZ, 12(1), 15-29.

Simpson, P. (2012). Apprehending everyday rhythms: rhythmanalysis, time-lapse photography, and the space-times of street performance. Cultural Geographies, 19(4), 423-445. doi:10.1177/1474474012443201

Tekin, İ. (2005). Beyoğlu-İstiklal Caddesi ve yakın çevresinde kentsel yaşamın kesitler üzerinden okunması ve caddede kalabalı (Yüksek lisans tezi). İstanbul Teknik Üniversitesi, Fen Bilimleri Enstitüsü, İstanbul.

Türk Dil Kurumu (2021). 1 Haziran 2021 tarihinde https://www.etimolojiturkce.com/kelime/ritm adresinden erişildi. 
Wunderlich, F. M. (2016). Symphonies of urban places: Urban rhythms as traces of time in space. A study of urban rhythms. 28 Aralık 2020 tarihinde https://rhuthmos.eu/spip.php?article1854 adresinden erişildi.

Zecca, C., Gaglione, F., Laing, R. ve Gargiulo, C. (2020). Pedestrian routes and accessibility to urban services: rhythmic analysis on people's behaviour before and during the Covid-19. Tema. Journal of Land Use, Mobility and Environment, 13(2), 241-256. doi:http://dx.doi.org/10.6092/1970-9870/7051 